\title{
Potential Output and Productivity
}

THE UNUSUAL TURMOIL in the U.S. economy during the 1970s has forced a reexamination of many of its macroeconomic characteristics. Inflation has been the most surprising feature of the period and the investigation of its causes and search for cures have been intense. The worsening of the relation between inflation and unemployment has been a focus of that investigation and has been linked, in part, to the very high unemployment rates experienced by younger members of the work force and to the remarkable rise in participation rates of young persons and adult women. These same developments bear on the measurement of potential gross national product, an important underpinning of both macroeconomic analysis and economic policymaking.

The 1974-75 recession and its aftermath have sparked reestimates of potential GNP that are substantially lower than the previous official estimates and that anticipate a slower growth of potential in coming years than previous official projections. The Council of Economic Advisers lowered the former estimate of 1976 potential by $\$ 58$ billion (1972 prices), reducing the gap between potential and actual GNP to $\$ 99$ billion. ${ }^{1}$ One element in this revision is a change in the unemployment rate at which potential is defined from the traditional 4 percent to a shifting rate that was 4.9 percent in 1976 . This adjustment is related to the higher unemployment rates experienced by younger workers and the declining

Note: I am grateful to Lisa L. Blum for extensive research assistance, to Evelyn M. E. Taylor for typing, and to Andrea V. Mills for computational help. Edward F. Denison kindly provided me with data from his own forthcoming study.

1. Economic Report of the President, January 1977, pp. 52-56. 
proportion of adult males in the total work force. Another important element in the CEA revisions is the observed weakness in productivity since 1973. Output per hour in the (nonresidential nonfarm) business sector declined by $3 \frac{1}{2}$ percent in 1974 , the first decline of any size in the postwar years. Despite a sharp increase during the 1976 economic recovery, productivity that year was still only $21 / 4$ percent above the 1973 level. The CEA analysis associates this weakness with an inadequate rate of capital accumulation and with the sharp rise in energy prices that coincided with the recession. These factors also lead them to project a potential growth rate of only $31 / 2$ percent a year through $1980 .{ }^{2}$ Data Resources, Inc., has published an analysis that lowers the estimate of the present growth rate of potential even further, to 3.35 percent. $^{3}$

A different challenge to traditional estimates of potential output has come from those who question the effect of unemployment on labor force participation. The sustained growth of the labor force right through the 1974-75 recession years surprised many observers. If this recent strength of participation rates is viewed as evidence of their insensitivity to unemployment, the traditional markup of the labor force of secondary workers that is used in calculating potential output is called into question. Without a large induced rise in the work force between today's actual economy and its potential, the present GNP gap would be substantially smaller than calculations such as Okun's law imply. Theoretical reasons for questioning any direct link between unemployment and the size of the labor force have been provided by economists who look, instead, for a substantial response of labor force participation to wages and prices. Michael Wachter has raised such doubts about the cyclical behavior of participation rates in his own empirical estimates of labor force behavior. ${ }^{*}$

This paper will reevaluate the evidence on the recent and prospective behavior of potential output. The issues just raised will be examined against the background of a previously successful approach to estimating potential. ${ }^{5}$ The analysis will start with the growth in the labor force, which

2. The analytic background for the CEA revisions is available in Peter $\mathrm{K}$. Clark, "A New Estimate of Potential GNP" (Council of Economic Advisers, 1977; processed).

3. Roger Brinner, "Potential Growth to 1980," in Otto Eckstein and others, Economic Issues and Parameters of the Next 4 Years (Data Resources, Inc., 1977).

4. Michael L. Wachter, "A Labor Supply Model for Secondary Workers," Review of Economics and Statistics, vol. 54 (May 1972), pp. 141-51.

5. George L. Perry, "Labor Force Structure, Potential Output, and Productivity," $B P E A, 3: 1971$, pp. 533-65. 
is an important building block in estimates of potential and is of considerable interest in itself.

\section{Labor Force Participation}

The substantial differences in the labor force behavior of different demographic groups make it essential to analyze growth in the labor force on a disaggregated basis. At a minimum, data are available by age-sex categories; and with some sacrifice in statistical reliability and historical continuity, some further disaggregations are possible. For a given population cell, it is useful to decompose labor force growth into changes in the population and changes in participation rates-the proportion of the population in the work force. Analysis of labor force growth then focuses on participation rates of individual population groups.

Rising participation by teenagers and women has been the outstanding and surprising feature behind the rapid growth of the labor force in the past decade. Sociological hypotheses to explain this changing behavior come readily to mind: the greater independence of teenagers, the changing values and attitudes fostered by the women's movement, the better family planning made possible by superior contraceptives, all must be involved. More narrowly economic hypotheses can be offered as well, built around the inflation of the last decade and the change in real living standards compared with expectations.

To analyze the present level of potential output and its past growth, one needs estimates of the cyclical response of participation rates so that the labor input available along the potential path can be measured. I start with some conventionally estimated equations for participation rates and then consider whether alternative hypotheses about the observed growth in participation can improve these calculations.

\section{CYCLICAL VARIATIONS IN PARTICIPATION}

According to the conventional view, participation rates for some demographic groups vary both cyclically, with a larger fraction of the population in the labor force when unemployment is low, and secularly, for reasons that are independent of the unemployment rate. Lacking any good way to identify and quantify the factors behind secular changes, past research has generally allowed for them by using time-trend variables. After 
some experimenting, the following form of estimating equation was used for each of fourteen demographic groups in the present analysis:

$$
\log (L / P)=A_{0}+a_{1} u^{*}+a_{2} u^{*}(-1)+a_{3} T 54+a_{4} T 67,
$$

where $L$ is the total labor force and $P$ is population; $u^{*}$ and $u^{*}(-1)$ are this year's and last year's weighted unemployment rates, respectively; and T54 and T67 are time-trend variables starting at 1 in 1954 and 1967, respectively, and rising by 1 each year. ${ }^{6}$ The concept of a weighted unemployment rate as a measure of labor market tightness is by now familiar. ${ }^{7}$

The form of the dependent variable was chosen after some preliminary comparisons between it and log $(1-L / P)$, the "nonparticipation rate," showed no persistent superiority for either. One worked slightly better for some groups and slightly worse for others. Using the nonparticipation rate required more abrupt trend changes (since it makes trends in participation rise more slowly with time when, in fact, they speeded up for some groups). And, while a constant trend growth rate in participation rates such as equation 1 implies cannot go on forever, that only warns against extrapolating it too far into the future.

The choice of a second time trend starting in 1967 was made after experimenting with starting points in 1964 and 1970 . Once again, some trends fitted better for some population groups and worse for others. The trend starting in 1964 sometimes reduced the estimated cyclical responsiveness of participation rates, presumably because more of the strong rise that occurred as unemployment fell between 1964 and 1966 was attributed to trend. These equations generally did not fit the data quite as well as the others. And 1964 predated the sociological changes that are hypothesized to lie behind the strongly rising participation trends of teenagers and younger women.

There was less difference between the estimates using the time trends

6. The data on the labor force, employment, and unemployment used here and throughout the paper (except as noted) are official estimates and are adjusted for Census-year changes and the changes in definition introduced in 1967. They are further adjusted to an employment basis (largely an establishment basis) that corresponds to the output categories in the GNP accounts. The adjustments are described in the appendix to Perry, "Labor Force Structure." The necessary data for the adjustment to an employment basis corresponding to GNP were provided by Edward F. Denison from his worksheets for a forthcoming study.

7. The version in this paper uses the proportions of different demographic groups in the labor force in 1966 together with the relative-wage and average-hour factors of each group that were explained in George L. Perry, "Changing Labor Markets and Inflation," BPEA, 3:1970, pp. 411-41. 
starting in 1967 and 1970, and also less a priori basis for preferring one to the other. The appendix summarizes the cyclical response, time trends, and goodness of fit of equations fitted to each demographic group using these alternative time trends and some alternative periods of estimation. In general, using a time trend starting in 1970 resulted in slightly greater cyclical responsiveness. So did ending the estimation period in 1973, before the great recession. Since all the estimates show a very strong cyclical responsiveness in participation, I chose the most conservative, the equations using the trend starting in 1967 and estimated from 1954 to 1976 , which includes the period of particular interest for estimating potential in this study. ${ }^{8}$

Table 1 shows the estimated equations for the participation rate for each of the demographic groups. Since the several equation forms shown in the appendix were compared before the form of equations shown in table 1 was selected, the basis for retaining coefficients relies on all the estimates shown in the appendix. All the unemployment coefficients in table 1 have a $t$ statistic of at least 1.6 ; the $t$ statistics were usually higher in equations using a time trend starting in 1970. Time-trend coefficients were kept if their $t$ statistics were greater than 1.5; for all but the over-65 age group, they are at least 2.0 in the table 1 estimates.

For both sexes in the groups aged 16 to 24 and for women in the groups aged 25 to 44 , a statistically significant and quantitatively important speedup in the trend of participation rates is found using the 1967 time dummy. For teenagers and women aged 25 to 34 , this acceleration is a strikingly large 3 to 4 percent a year (on a base of roughly 0.5 for participation rates in these groups). Men 25 to 64 and women 45 and over show a statistically significant slowing in participation rates using the 1967 time dummy. The net result of the time trends on participation rates over the last ten years is shown in the last column of table 1 . Sharply rising trends are estimated for women of all age groups between 16 and 44, with the average annual rate of increase ranging between about $2 \frac{1}{2}$ and 4 percent. Teenage males also show a pronounced upward trend, while men over 54 and women over 64 have steep downward trends. The trends for other demographic groups are much more gradual.

8. Using the same form of the trend, as well as the dependent variable, for all the demographic groups was a way of minimizing the effects of the data mining that would have gone with selecting a "best-fitting" equation for each group after experimenting with so many alternatives. 


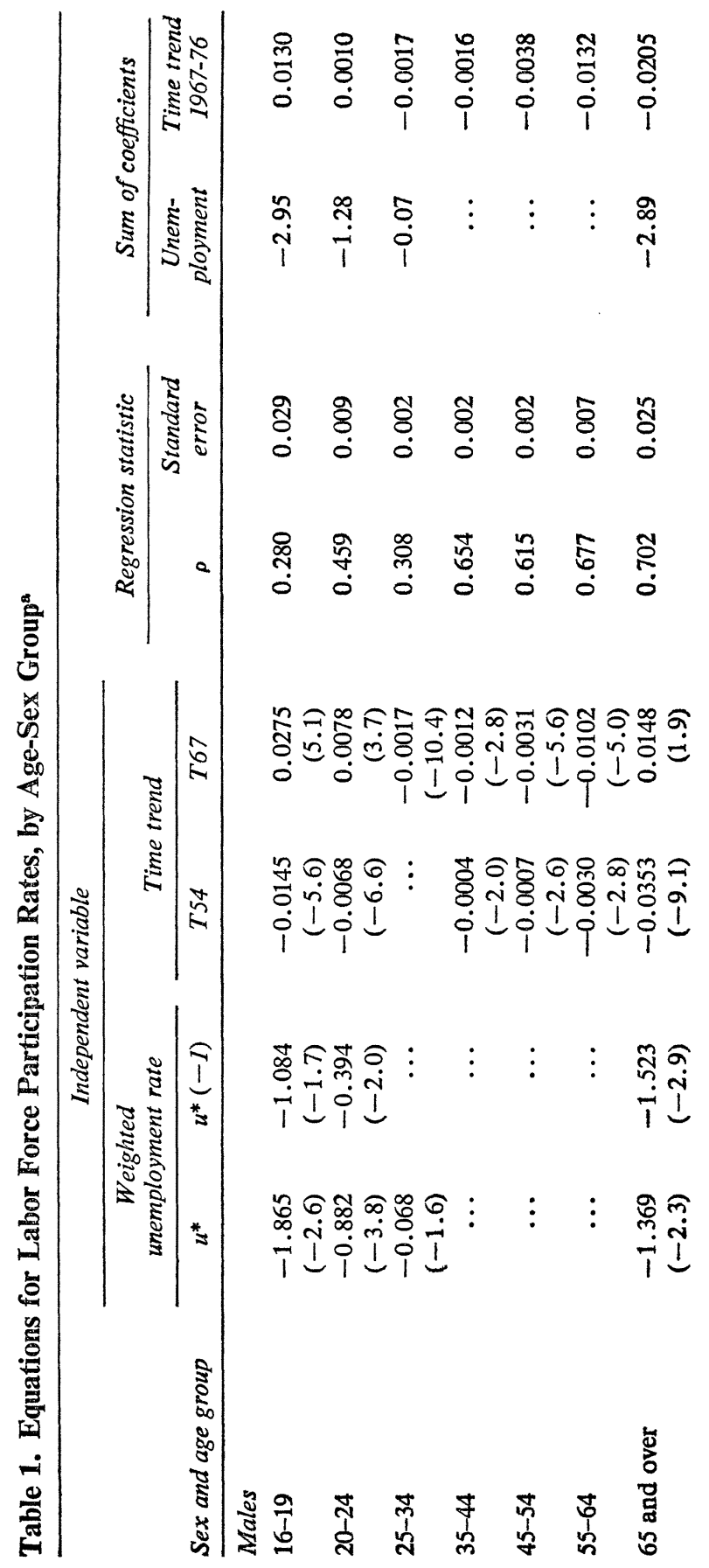




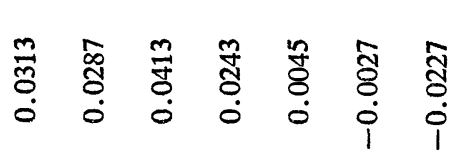

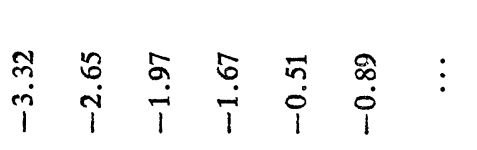

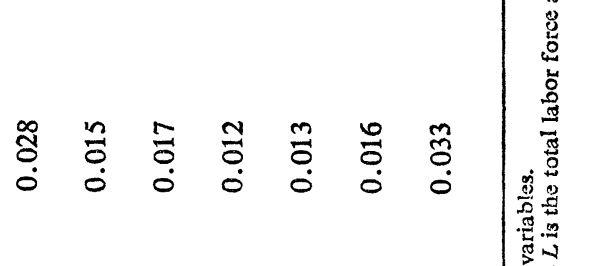

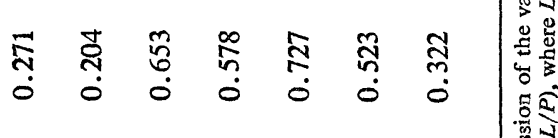

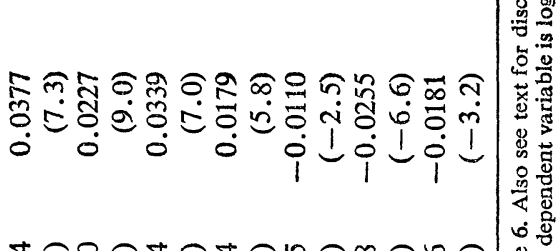

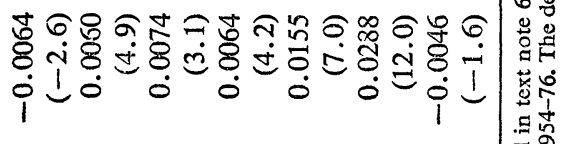

$$
\begin{aligned}
& \text { กิน }
\end{aligned}
$$

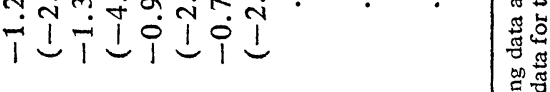

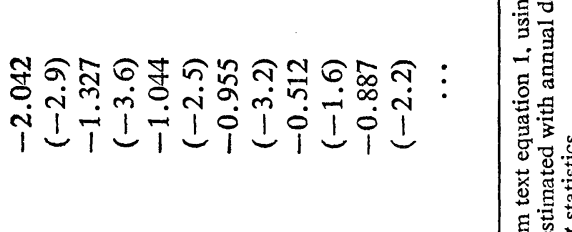


Cyclical Response. The cyclical responsiveness of participation rates is summarized in the next to last column of table 1 , which shows the percentage change in participation (or the labor force) that would accompany a sustained increase of 1 percentage point in the weighted unemployment rate. Although these estimates are the most conservative of those available from the several alternatives shown in appendix table A-1, they do predict a stronger cyclical response, particularly for recent years, than many earlier studies. According to previous estimates summarized by Okun, a one-point decline in unemployment added 0.6 percent to the labor force. ${ }^{9}$ For 1976 , the present estimates indicate that an increment in the labor force of about 0.9 percent accompanies each point of unemployment. However, since the large increments to the work force are concentrated among young workers and younger adult women-workers who, on the whole, receive relatively low productivity weights in the subsequent estimates of potential labor input - the potential output calculations are not overly influenced by this difference in estimates of cyclical participation-rate effects. If the labor force increments were only three-fourths as large, thus bringing them down to the average cited by Okun, potential (weighted) labor input in 1976 would be only about 0.25 percent below what is estimated using the table 1 equations.

Part of the reason for the large participation effects estimated in the table 1 equations comes from effects from lagged unemployment that turn up in the current equations. And part results from the increased relative importance of women and teenagers in today's work force. The table below analyzes the changing cyclical responsiveness of the aggregate labor force (in terms of percentage change) that results from this changing mix.

$\begin{array}{lllll}1955 & 1960 & 1965 & 1970 \quad 1976\end{array}$

Change per point

of weighted unemployment

Change per point of conventional unemployment

0.82

0.87

0.95

1.02

In terms of a point of weighted unemployment, the responsiveness increased by about one-quarter between 1960 and 1976. The change is less marked in terms of conventional unemployment rates; the two changes are different because the cyclical relation between conventional and

9. Arthur M. Okun, "Upward Mobility in a High-Pressure Economy," $B P E A$, 1:1973, pp. 210-11. 
weighted unemployment has also shifted over this period. The relation between the conventionally measured unemployment gap $(u-\bar{u})$ and the weighted unemployment gap $\left(u^{*}-\bar{u}^{*}\right)$ is estimated by the equation

$$
\begin{gathered}
u-\bar{u}=\underset{(65.7)}{0.996\left(u^{*}-\bar{u}^{*}\right)}+\underset{(6.7)}{0.0127\left[T\left(u^{*}-\bar{u}^{*}\right)\right],} \\
\text { Standard error }=0.00072 ; \text { Durbin-Watson }=1.9 .
\end{gathered}
$$

where $T$ is a time-trend variable starting in 1964 and the numbers in parentheses are $t$ statistics (as they are in the equations throughout this paper). The levels of unemployment used to define potential, $\bar{u}^{*}$ and $\bar{u}$, are discussed and defined below in connection with estimating the potential labor force. Equation 2 is used to calculate the second row of the table, which shows that the changing mix of the labor force accounts for about onequarter of the difference between the present estimates of the cyclical effects on labor force participation for 1976 and those cited by Okun. The remaining difference-between 0.6 percent and the 0.82 percent average for 1955-60 in the present estimates-is attributable to the lagged unemployment effects and other differences in the form of the estimating equations.

\section{EXPLAINING THE TRENDS}

Several attempts were made to get behind the time trends shown in the table 1 equations in the hope of improving the specifications and of better identifying the cyclical effects and also of providing a stronger foundation for projecting future participation rates. First, the proportion of black males in the adult age groups was introduced as an explanatory variable, but did not account for the decline in these groups. Furthermore, participation rates for both black and white adult males declined in recent years. Second, the proportion of 16- to 19-year-olds enrolled in school was a significant variable in explaining participation of females in this age group. However, it left both the time trend starting in 1967 and the unemployment effects almost identical to those in the table 1 equations, although it reduced the time trend before 1970 . The enrollment variable was insignificant for teenage males. Finally, the ratio of college enrollments of women and men was tried as a proxy for the sociological changes affecting women's participation. But it resulted in substantially higher standard errors for the equation than the time trend did and took on the wrong sign in some cases. 
Table 2. Labor Force Participation Rates of Women, by Marital and Parental Status, and Age Groups, 1967 and 1975

Percent

\begin{tabular}{|c|c|c|c|c|c|c|}
\hline \multirow{2}{*}{$\begin{array}{l}\text { Parental status } \\
\text { and age group }\end{array}$} & \multicolumn{2}{|c|}{$\begin{array}{l}\text { Married women, } \\
\text { husband present }\end{array}$} & \multicolumn{2}{|c|}{$\begin{array}{l}\text { Other ever- } \\
\text { married women }\end{array}$} & \multicolumn{2}{|c|}{$\begin{array}{c}\text { Never- } \\
\text { married women }\end{array}$} \\
\hline & 1967 & $1975^{\mathrm{a}}$ & 1967 & $1975^{a}$ & 1967 & $1975^{\mathrm{a}}$ \\
\hline \multicolumn{7}{|c|}{ With no children under 18} \\
\hline $16-19$ & 43.3 & 61.9 & 48.9 & 47.0 & 37.2 & 49.6 \\
\hline $20-24$ & 67.2 & 84.2 & 75.6 & 82.9 & 70.3 & 72.4 \\
\hline $25-34$ & 70.4 & 84.2 & 69.9 & 86.0 & 80.9 & 84.6 \\
\hline $35-44$ & 59.2 & 65.6 & 54.8 & 82.3 & 74.5 & 79.8 \\
\hline 45 and over & 31.8 & 34.6 & 29.7 & 29.3 & 47.4 & 49.3 \\
\hline \multicolumn{7}{|l|}{ With children $6-17$} \\
\hline $16-19$ & $\ldots$ & $\ldots$ & $\ldots$ & $\ldots$ & $\ldots$ & $\ldots$ \\
\hline $20-24$ & $45.2^{b}$ & 42.0 & 39.1 & 64.3 & $\ldots$ & $\ldots$ \\
\hline $25-34$ & 49.0 & 60.3 & 72.9 & 77.0 & $\ldots$ & $\ldots$ \\
\hline $35-44$ & 46.1 & 57.5 & $68.5^{b}$ & 75.0 & $\ldots$ & $\ldots$ \\
\hline 45 and over & 41.3 & 47.1 & 59.8 & 60.5 & $\ldots$ & $\ldots$ \\
\hline \multicolumn{7}{|c|}{ With children under 6} \\
\hline $16-19$ & 20.9 & 34.9 & 27.6 & 44.2 & $\ldots$ & $\ldots$ \\
\hline $20-24$ & 29.3 & 40.8 & 52.2 & 64.5 & $\ldots$ & $\ldots$ \\
\hline $25-34$ & 25.5 & 39.0 & 52.5 & 59.2 & $\ldots$ & $\ldots$ \\
\hline $35-44$ & 26.9 & 35.5 & 51.8 & 47.1 & $\ldots$ & $\ldots$ \\
\hline 45 and over & 26.8 & 31.7 & 47.5 & 53.3 & $\ldots$ & $\ldots$ \\
\hline
\end{tabular}

Source: U S. Bureau of Labor Statistics.

a. 1975 data are adjusted for the difference between the aggregate unemployment rates for 1967 and 1975 using the equations developed in the text. Unlike the other data in this paper, the data in this table are not adjusted for the 1970 Census and are not adjusted to an establishment-employment basis.

b. The 1966 value was used due to an apparent error in the 1967 figures.

Family Status. For women, family status has been an important factor determining labor force participation. The importance of changes in status for the recent changes in participation trends was examined with the data in table 2. There, participation rates are given for 1967 and 1975 for the female population disaggregated according to three categories for marital status, three for number of children, and five for age. To eliminate cyclical effects in comparing the two years, the raw data for 1975 were adjusted for the difference in weighted unemployment between 1967 and 1975 using the equations of table 1. Participation rates rose between 1967 and 1975 in almost all of the thirty-three cells but rose only a little for women 20 and over who had never been married and for women 45 and over.

The proportion of women in different cells has shifted along with the changes in behavior for each cell. Table 3 shows the relative importance of these two sources of total change: (1) the change that would have oc- 
Table 3. Population-Shift and Behavioral-Change Effects on Labor Force Participation Rates of Women, by Age Group

Percentage points

\begin{tabular}{lccc}
\hline & \multicolumn{3}{c}{ Change in participation rates, } \\
\cline { 2 - 4 } Age group & Total & $\begin{array}{c}\text { Change } \\
\text { within family- } \\
\text { characteristic cells } s^{\mathbf{z}}\end{array}$ & $\begin{array}{c}\text { Shift } \\
\text { among family- } \\
\text { characteristic cells }^{\mathbf{a}}\end{array}$ \\
\hline $16-19$ & 12.9 & 12.7 & 0.1 \\
$20-24$ & 13.6 & 8.9 & 4.7 \\
$25-34$ & 16.2 & 11.9 & 4.8 \\
$35-44$ & 12.1 & 10.2 & 2.2 \\
45 and over & 2.0 & 2.0 & 0.0 \\
All groups & 8.7 & 6.9 & 1.8 \\
\hline
\end{tabular}

Source: Calculated from table 2. Figures are rounded.

a. For explanation, see text.

curred had the population distribution among cells remained unchanged while participation rates in each cell changed as they actually did between 1967 and 1975 (in the table, this part of the total change is labeled "change within family-characteristic cells"); (2) the change that would have occurred had participation rates in each cell remained unchanged while the population distribution among cells changed as it actually did between 1967 and 1975 (in the table, this part of the total change is labeled "shift among family-characteristic cells").

Although the effect of the second kind of change-in the distribution of family status with participation rates fixed-is noticeable, particularly for the groups between 20 and 34, the changes in behavior within each cell between the two years is easily the more important source of the observed shift in participation rates. Of course, both sources of change can reflect a common sociological trend. A woman's decision not to marry or not to have children can have the same motivations that lead her to join the work force.

The results in tables 2 and 3 permit no hard conclusions, but they invite a few conjectures. First, the far greater importance of changes in participation for a given group relative to population shifts among groups suggests some permanence in recent developments. Even if the distribution of various kinds of family status moves back toward its earlier pattern because marriage and child-bearing turn out to have been postponed rather than forgone, large changes in participation would remain. Second, the uneven distribution of changes in participation suggests that they are based on sociological factors rather than on shorter-run economic developments 
in inflation and real earnings. All groups should have been affected by economic developments, yet only women under 45 displayed substantial changes in behavior, either on balance or within family-characteristic cells. This finding is supported by the time trends in the equations of table 1. Third, there is room for a substantial further increase in overall participation rates of women. The age groups that have been affected will continue in the working-age population for many years, while those 45 years and over who have not been affected (or who show a declining trend in the results of table 1) will be leaving it. Women 25 to 34 without children may have approached normal limits in their participation since the participation rates of never-married women are matched by those for the two other cells. But apparently there is still scope for higher participation among women with children if their behavior continues, as it has over the past decade, to narrow the gap between those with and without a husband present.

\section{THE ROLE OF WAGES AND PRICES}

The model of labor force participation of equation 1 is obviously incomplete. One of its sins of omission is its failure to take explicit account of wages and prices. I tried to incorporate them, drawing on an alternative model of participation developed by Wachter. ${ }^{10}$ The variables he used were the real wage, $W$, and the price level, $P$, and moving averages of their past values, $W^{*}$ and $P^{*}$, which were used to represent the "permanent" wage and the "perceived" level of prices. Wachter uses the perceived real wage and the ratio of the current to the perceived real wage as explanatory variables to model the effects on labor supply of permanent and transitory movements in real wages. The ratio of the current to the perceived price level measures the money illusion that fools workers into entering the labor market. The expected sign on the price-ratio variable is positive, while the expected sign on the two wage variables depends on the group whose participation is being analyzed.

In order to examine their effects on participation, the variables that Wachter specified were added to those of equation $1 .{ }^{11}$ Table 4 gives the

10. Wachter, "Labor Supply Model."

11. $W^{*}$ is an eight-year moving average of $W$, the real wage, defined as total private nonagricultural adjusted hourly earnings deflated by $P$, the consumer price index; and

$$
P^{*}=0.4 P+0.3 P(-1)+0.2 P(-2)+0.1 P(-3) .
$$




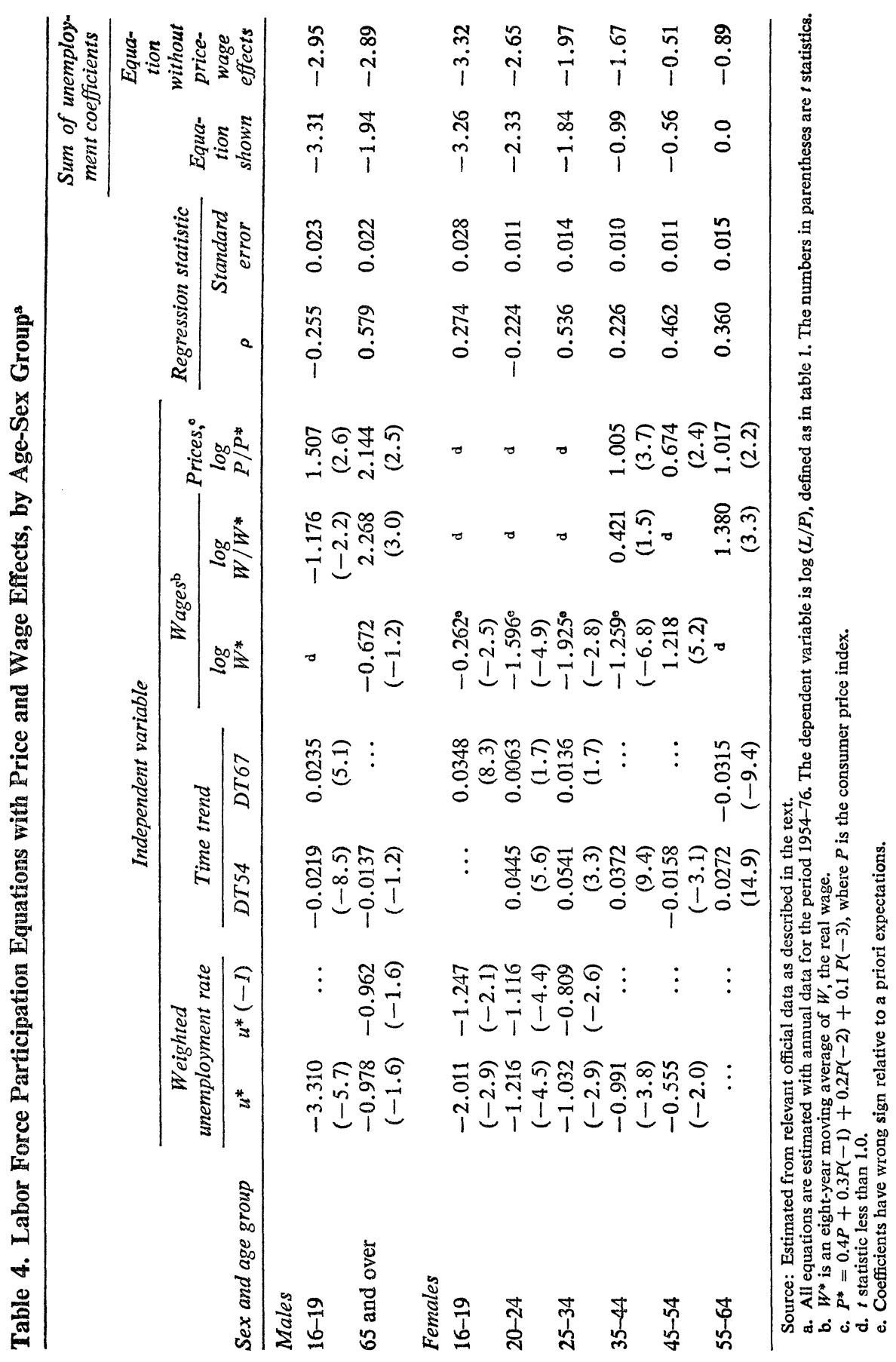


estimates resulting from fitting this equation to annual data over the period 1954-76 for those demographic groups that Wachter used in his own tests. The years before 1954 were unavailable because of the long lags required in forming the variables. But the inflation since his stopping point of 1968 should provide a good test of the role of wages and prices in the model for labor supply.

The results in table 4 support the basic model of equation 1 in most respects. Each of the new variables was included if its $t$ statistic was at least 1.0. Despite this lenient criterion, most of the variables reflecting the relative real wage were omitted as insignificant. Only two of six actual real-wage variables were significant and correctly signed, while four others had significant coefficients with incorrect signs. ${ }^{12}$ The inflation variables were much more successful, with significant coefficients appearing in five of the eight equations.

As the last two columns of table 4 show, the addition of the wage and price variables had only a modest effect on the cyclical response of the model. They do produce noticeable changes in the time trends for some groups. In particular, compared with the results of table 1 , the trend growth in participation is noticeably faster for females between 20 and 44 and for male teenagers.

\section{CHANGING PERMANENCE OF PARTICIPATION}

One final hypothesis concerning cyclical response was checked out. If the rise in participation rates of the past decade was part of a more permanent attachment to work on the part of secondary workers, the cyclical responsiveness of participation could be expected to decline. This would mean that the average coefficients on unemployment shown in table 1 were too large for the labor force of recent years. But table 5, which gives the unemployment coefficients of the table 1 equations separately for the 1954-65 and 1966-76 periods, suggests that this is not the case. The coefficients are actually larger (more negative) for six of the ten population groups in the latter period.

12. Since the signs on the wage and relative-wage variables vary according to which theory applies, I have shown all significant coefficients and have used Wachter's criteria as expressed in his results and discussion to determine what signs are expected. 
Table 5. Comparison of Cyclical Responsiveness of Labor Force Participation, by Age-Sex Group, 1954-65 and 1966-76

Sum of unemployment coefficients

\begin{tabular}{lrl}
\hline Sex and age group & $1954-65$ & $1966-76$ \\
\hline Males & & \\
$16-19$ & -2.69 & -3.04 \\
$20-24$ & -0.80 & -1.47 \\
$25-34$ & 0.03 & -0.12 \\
65 and over & -2.38 & -3.03 \\
Females & & \\
$16-19$ & -2.95 & -3.09 \\
$20-24$ & -3.10 & -2.37 \\
$25-34$ & -2.23 & -1.67 \\
$35-44$ & -1.79 & -1.29 \\
$45-54$ & -0.23 & -0.52 \\
$55-64$ & -1.00 & -0.52 \\
\hline
\end{tabular}

Source: Equations of table 1 were used, with estimated effects of right-hand variable other than unemployment subtracted from the dependent variable and the remaining unemployment effect estimated separately for each period shown.

\section{Potential Labor Input}

Since their unemployment effects seemed reasonably stable through time and were much the same whether or not price and wage variables were included, the participation equations of table 1 were used to adjust for the cyclical variations in the size and composition of the labor force and employment. For this purpose, a constant weighted unemployment rate of 3.32 percent-its value in mid-1955-was taken as an index of potential, with cyclical variations measured by cleviations of weighted unemployment from this constant level.

\section{DEFINING POTENTIAL}

Since a definition of potential is needed and is being introduced here, this is as good a place as any to explain the choice. Because everyone is used to it and understands it, I depart only reluctantly from a constant conventional unemployment rate as the index of the economy at potential. Yet the weighted unemployment rate has the obvious advantage that it 
represents unemployed labor in efficiency units. And its counterpart, weighted employment, has proven useful in aggregate production functions.

One might want to define potential by a measure that represented a "noninflationary" level of utilization or unemployment. An appropriate level of constant weighted unemployment is a step in that direction. But it would be misleading to think of such a measure as defining a noninflationary operating point with any precision, and it is not meant to serve that purpose. Even when I first used it, I noted that weighted unemployment was an imperfect measure of overall labor market tightness because it failed to account for the changing dispersion of unemployment rates. And everyone now knows that inflation can arise from causes other than overly tight labor markets, and that once under way, it can continue despite enormous slack in capacity and high unemployment. Furthermore, if policies directly affect the price-wage level-through structural measures aimed at high unemployment areas, incomes policies, or microeconomic policies-the link between weighted unemployment and inflation is weakened further.

Analysis of potential output provides information about the relation between output and unemployment and about the cyclical and trend characteristics of productivity, labor input, and output in the economy. An understanding of these relationships is important to any macroeconomic investigation. The concept of weighted unemployment that is used in this analysis approximates overall tightness in labor markets in a way that is useful for studying inflation and certainly more useful than conventional unemployment. But using a level of constant weighted unemployment as a base for measuring potential does not imply that that base gives the optimal operating level of the economy at all times, or that inflation will always be absent or declining if that rate is maintained. Choosing the optimal level that balances risks of inflation against costs of unemployment and underutilization will continue to be an issue for year-by-year analysis and for debate within the political process.

\section{POTENTIAL EMPLOYMENT AND HOURS}

The potential labor force in each age-sex group $\left(\bar{L}_{i}\right)$ in each year was calculated by adding to the actual labor force the cyclical increment pre- 
dicted by the table 1 equations. The unemployment rate at potential for each group was then estimated using the restriction that

$$
\frac{U_{i}+\bar{L}_{i}-L_{i}}{\bar{L}_{i}}=\alpha \frac{\bar{U}_{i}}{\bar{L}_{i}}
$$

for each group, where $U$ is unemployment and bars over the variables represent values at potential; that is to say, the ratio of the actual "total" unemployment rate (which includes the shortfall in participants) to the unemployment rate at potential is the same for each group. The constant $\alpha$ was calculated for each year from the constraint that the weighted unemployment rate was 0.0332 :

$$
\alpha \Sigma \beta_{i} h_{i} w_{i} \frac{\bar{U}_{i}}{\bar{L}_{i}}=0.0332,
$$

where the $\beta_{i}$ are the relative labor force weights of 1966; the $h_{i}$ and $w_{i}$ are the hour and wage weights, respectively; and $\Sigma \beta_{i} h_{i} w_{i}=1$. Employment at potential for each group is $\bar{E}_{i}=\bar{L}_{i}-\bar{U}_{i}$; total employment is $\bar{E}=\Sigma \bar{E}_{i} ;$ and total weighted employment is $\overline{W E}=\Sigma h_{i} w_{i} \bar{E}_{i}$.

Along the potential path, the unemployment rate has risen gradually over the past twenty years, as shown in table 6 . There, the armed forces are excluded to make the data comparable with the familiar published unemployment rates. ${ }^{13}$ The unemployment rate at potential is estimated as 4.9 percent in 1976 , the same as CEA's estimate, compared with 4.0 percent in the mid-1950s. Unemployment was clearly below its potential level in two sustained wartime stretches, from 1951 through 1953 and from 1966 through 1969. It was about at potential in 1955-57 and in 1965 and 1973. In the fifteen remaining years, unemployment was above potential levels, with the biggest excess occurring in the last two years.

Employment Gaps. Table 7 shows the percent employment gap estimated for each demographic group per point of aggregate unemployment. The relative gains in employment experienced by each group are slightly different in 1960-61 and 1975-76 because of differences in their relative shares of total employment and unemployment in the two periods. But in

13. In this table and all subsequent tables with economic variables on the potential path, potential values are given by three-year centered moving averages of the directly calculated potential variables. This removes some of the irregularities that would otherwise arise from residuals in the estimated equations that are used to calculate potential magnitudes, and from abrupt changes introduced by time trends. 
Table 6. Conventional Unemployment Rates, Actual and Potential, 1950-76

Percent

\begin{tabular}{cccc}
\hline Year & Actual & Potential & $\begin{array}{c}\text { Actual minus } \\
\text { potential }\end{array}$ \\
\hline 1950 & 5.2 & 4.0 & 1.2 \\
1951 & 3.1 & 3.9 & -0.8 \\
1952 & 2.8 & 3.7 & -0.9 \\
1953 & 2.7 & 3.6 & -0.9 \\
1954 & 5.3 & 3.8 & 1.6 \\
1955 & 4.2 & 4.0 & 0.3 \\
1956 & 4.0 & 4.0 & 0.0 \\
1957 & 4.1 & 4.0 & 0.2 \\
1958 & 6.7 & 4.0 & 2.7 \\
1959 & 5.4 & 4.1 & 1.3 \\
1960 & 5.4 & 4.1 & 1.3 \\
1961 & 6.6 & 4.1 & 2.5 \\
1962 & 5.5 & 4.2 & 1.2 \\
1963 & 5.6 & 4.3 & 1.3 \\
1964 & 5.1 & 4.4 & 0.8 \\
1965 & 4.4 & 4.4 & 0.0 \\
1966 & 3.6 & 4.4 & -0.8 \\
1967 & 3.8 & 4.4 & -0.6 \\
1968 & 3.6 & 4.5 & -0.9 \\
1969 & 3.5 & 4.5 & -1.0 \\
1970 & 5.0 & 4.5 & 0.4 \\
1971 & 6.0 & 4.6 & 1.3 \\
1972 & 5.6 & 4.8 & 0.9 \\
1973 & 4.8 & 4.8 & 0.0 \\
1974 & 5.6 & 4.8 & 0.8 \\
1975 & 8.5 & 4.8 & 3.7 \\
1976 & 7.7 & 4.9 & 2.8 \\
\hline
\end{tabular}

Sources: Actual from Bureau of Labor Statistics, with rates adjusted for Census-year changes and 1967 definition changes. The calculation of unemployment rates at potential is described in the text.

a. Calculated from unrounded unemployment rates.

both periods the story is much like Okun's calculations based on my earlier analysis of potential. ${ }^{14}$

Employment Composition. Through time, the changing demographic composition of employment has been the result of two developments: the changing composition of the labor force and changing relative unemployment rates. Since, for the most part, those groups that have grown the

14. Okun, "Upward Mobility," pp. 216-17. 
Table 7. Employment Gaps by Age-Sex Group per Point of the Unemployment Rate, 1960-61 and 1975-76

Percent

\begin{tabular}{lcc}
\hline Sex and age groups & $1960-61$ & $1975-76$ \\
\hline Males & & \\
$16-19$ & 5.4 & 5.5 \\
$20-24$ & 2.6 & 3.0 \\
$25-34$ & 1.2 & 1.2 \\
$35-44$ & 0.9 & 0.8 \\
$45-54$ & 1.1 & 0.8 \\
$55-64$ & 1.3 & 0.8 \\
65 and over & 2.5 & 2.3 \\
Females & & \\
$16-19$ & 5.3 & 5.9 \\
$20-24$ & 3.7 & 3.7 \\
$25-34$ & 2.8 & 2.6 \\
$35-44$ & 2.3 & 2.0 \\
$45-54$ & 1.6 & 1.3 \\
$55-64$ & 1.5 & 1.4 \\
65 and over & 0.7 & 0.9 \\
\hline
\end{tabular}

Source: Author's estimates based on participation equations and calculation of potential employment described in the text.

fastest have also experienced a deterioration in unemployment rates relative to other groups, the composition of employment has changed slightly less than the composition of the labor force. The employment along the economy's potential path differs from the actual to the extent that the cyclical employment gains shown in table 7 are not proportional among the various demographic groups. Table 8 gives employment profiles of the economy, showing total employment and its demographic distribution for the actual economy and the estimated economy at potential. The estimate for 1981 in the table was obtained by projecting participation rates beyond 1976, making a conservative projection of the participation-rate equations in table 1. Rather than projecting a continuation of the estimated trends, which would maintain a constant percentage change, the average annual absolute change in participation rates over the past ten years was extended into the future. The resulting participation rates for each demographic group were multiplied by 1981 populations to obtain 1981 projections of the labor force. These, in turn, were multiplied by 1976 potential employment rates to obtain 1981 employment totals for each group.

The work force is maturing. The large increases in employment pro- 
Table 8. Actual and Potential Employment Profiles of the Economy, Selected Years 1955-81

\begin{tabular}{|c|c|c|c|c|c|c|c|}
\hline Description & 1955 & 1960 & 1965 & 1970 & 1975 & 1976 & $\begin{array}{l}\text { Projected } \\
\quad 1981\end{array}$ \\
\hline & \multicolumn{7}{|c|}{ Actual economy } \\
\hline $\begin{array}{l}\text { Unemployment rate } \\
\text { (percent) })^{\mathrm{a}}\end{array}$ & 4.2 & 5.4 & 4.4 & 5.0 & 8.5 & 7.7 & $\ldots$ \\
\hline $\begin{array}{l}\text { Total employment } \\
\text { (millions) } \\
\text { Employment propor- } \\
\text { tion (percent) }\end{array}$ & 65.8 & 67.9 & 73.4 & 81.9 & 86.4 & 89.0 & $\cdots$ \\
\hline 65 and over & 5.0 & 4.7 & 4.0 & 3.8 & 3.2 & 3.0 & $\cdots$ \\
\hline $16-19$ & 6.4 & 6.6 & 7.5 & 8.0 & 8.5 & 8.5 & $\ldots$ \\
\hline $20-24$ & 10.7 & 10.3 & 11.9 & 14.0 & 14.3 & 14.5 & \\
\hline \multicolumn{8}{|l|}{$25-64$} \\
\hline Female & 23.0 & 24.3 & 24.8 & 26.1 & 27.5 & 28.0 & $\ldots$ \\
\hline Male & 54.8 & 54.1 & 51.8 & 48.0 & 46.5 & 46.0 & $\cdots$ \\
\hline & \multicolumn{7}{|c|}{ Potential economy } \\
\hline $\begin{array}{l}\text { Unemployment rate } \\
\text { (percent) } \\
\text { Total employment }\end{array}$ & 4.0 & 4.2 & 4.4 & 4.5 & 4.9 & 4.9 & 5.1 \\
\hline (millions) $)^{\mathrm{a}}$ & 66.3 & 69.7 & 74.0 & 82.2 & 92.0 & 94.6 & 106.2 \\
\hline $\begin{array}{l}\text { Employment propor- } \\
\text { tion (percent) }\end{array}$ & & & & & & & \\
\hline 65 and over & 5.1 & 4.7 & 4.0 & 3.8 & 3.1 & 3.0 & 2.6 \\
\hline $16-19$ & 6.5 & 6.9 & 7.5 & 8.1 & 9.4 & 9.4 & 8.9 \\
\hline $20-24$ & 10.8 & 10.5 & 11.9 & 14.1 & 14.9 & 15.1 & 15.4 \\
\hline $25-64$ & & & & & & & \\
\hline Female & 23.0 & 24.4 & 24.8 & 26.1 & 27.4 & 27.9 & 30.0 \\
\hline Male & 54.7 & 53.6 & 51.7 & 48.0 & 45.1 & 44.6 & 43.1 \\
\hline
\end{tabular}

Source: Actual-Bureau of Labor Statistics; other-calculations underlying table 7. Figures are rounded. a. Unemployment rates exclude armed forces; employment totals and proportions include them.

portions for the groups aged 16 to 24 that have been occurring since 1960 are over except for the normal expansion in their share of jobs as cyclical unemployment is reduced (unless special government job programs add to their expected job total). The rise in the employment share of women aged 25 to 64 will actually accelerate as more women enter this mature age group and participation rates continue rising although at a more modest rate than in recent years. Finally, the share of men 25 to 64 in total employment declines more slowly than in recent years along the potential path, although the decline is substantial between 1976 actual and 1981 potential. These relative changes suggest that the specific problems of 
teenagers and young adults may lessen, while adult women may be in for a relatively more difficult period in the labor market as their numbers continue to increase sharply.

Potential Average Hours. Average hours worked per year per employee fluctuate cyclically and, in addition, have been on a clear downward trend throughout the postwar period. Both the cyclical and secular changes reflect the operation of several forces. Up through the mid-1950s, the normal workweek in manufacturing was being reduced to 40 hours. Since then, a gradual reduction in economy-wide average hours has continued, only in part as the result of the growing number of workers who voluntarily seek part-time work. My previous attempt at explaining the trend in hours adjusted for the changing composition of employment still left a major portion unexplained. ${ }^{15}$ So this time I have ignored that complication. Since the subsequent analysis will concentrate on the private nonresidential nonfarm business sector-hereafter, simply the "business sector"-for the period starting in 1954, the equation was fitted to average hours in that sector $(A H B)$ from 1954 to 1976 :

$$
\begin{aligned}
& \log A H B=3.72-0.494 u^{*}-0.00214 T 54-0.00310 T 66-0.00885 D T \text {. } \\
& (-5.5) \quad(-8.1) \quad(-5.6) \\
& \text { Standard error }=0.00324 \text {; Durbin-Watson }=2.1 \text {. }
\end{aligned}
$$

Three time-trend variables were needed: T54 starts at 1 in 1954 and rises by 1 each year; T66 starts at 1 in 1966 and rises by 1 each year; and $D T$ is 1 in 1966 and 2 in 1967 and subsequent years. Using a special time dummy for 1966 and 1967 is unsatisfying, but the data demand it. I have previously discussed my attempt to get behind this discontinuity, concluding then that the drop in hours should be regarded as a permanent shift downward in the hours trend. ${ }^{16}$ Now, with seven more years of data available, that conclusion seems reaffirmed. Nonetheless, estimating the cyclical and secular behavior of hours with an equation such as 3 remains one of the least satisfactory steps in the analysis of potential.

The coefficient on $u^{*}$ indicates that each extra point of weighted unemployment is accompanied by nearly 0.5 percent lower average hours in the business sector. In 1976, that corresponds approximately to 0.4 percent extra average hours per point of conventional unemployment. The trend terms indicate that, at present, average hours are falling by just over

15. Perry, "Labor Force Structure."

16. Ibid. 
0.5 percent a year along the potential path. With the changes in relative employment among demographic groups just projected, this rate of decline could lessen, but the equation provides no way of estimating that effect.

Potential Weighted Hours. The ingredients for calculating potential weighted hours are now at hand. Employment in each age-sex group was allocated to the business sector according to the ratio in each year of total employment in that sector to economy-wide employment. Employment in the business sector in each age-sex group, $E B_{i}$, was then weighted by relative hours and wages and summed to get weighted employment for the sector, $W E B$, and adjusted by average weekly hours to get weighted (total) hours, $H$, the basic measure of labor input. ${ }^{17}$ The difference in employment between actual and potential was all assigned to the business sector and the procedure repeated to obtain potential weighted hours, $\bar{H}$, for each year. ${ }^{18}$

The average annual growth rates in principal indicators of potential labor input are shown in table 9 over half-decade intervals and 1970-76. The last column projects the next five years. The growth rate of the labor force and employment more than doubles in the 1965-76 period from the previous decade, and growth in potential employment accelerates even more in the business sector than it does in the whole economy. The growth rate of weighted hours in the business sector does not speed up nearly as much as employment, both because of the sharp slowdown in average hours worked during that period and because a large part of the employment acceleration consists of workers with low hours and wages. But with average hours declining more slowly in the 1970-76 interval, potential weighted hours grow more than twice as fast as in the 1965-70 period. Because the potential employment increase continues to be relatively concentrated in workers with low weights (and average hours decline faster than in the pre-1965 intervals), the annual growth of potential weighted hours is a full percent slower than the growth of potential employment over the latest interval, a much larger difference than in the pre-1965 periods.

For the 1976-81 projection period, total employment and its composi-

17. The following formula was used to assign the appropriate weights consistent with the total hours of employment:

$$
H=A H B \frac{\Sigma E B_{i}}{\Sigma h_{i} E B_{i}} \Sigma h_{i} w_{i} E B_{i} .
$$

18. A justification for treating the rest of the economy as noncyclical is provided by Okun's results in "Upward Mobility," pp. 218-24. 
Table 9. Potential Growth Rates of Labor Input Measures, Selected Intervals, 1950-81

Percent per year

\begin{tabular}{lcccccc}
\hline \multicolumn{1}{c}{ Measure } & $1950-55$ & $1955-60$ & $1960-65$ & $1965-70$ & $1970-76$ & $\begin{array}{c}\text { Projected } \\
1976-81\end{array}$ \\
\hline Labor force & 1.43 & 1.01 & 1.29 & 2.17 & 2.39 & 2.08 \\
$\begin{array}{l}\text { Employment } \\
\text { Total }\end{array}$ & 1.45 & 0.97 & 1.23 & 2.14 & 2.31 & 2.07 \\
Total civilian & 1.05 & 1.17 & 1.22 & 2.10 & 2.59 & $\ldots$ \\
Business & 1.46 & 1.21 & 1.11 & 2.30 & 2.87 & 2.07 \\
Hours & & & & & & \\
Total business & 1.15 & 0.95 & 0.84 & 1.41 & 2.33 & 1.53 \\
Weighted total business & 1.06 & 0.81 & 0.59 & 0.94 & 1.81 & 1.39 \\
\hline
\end{tabular}

Source: Calculated as described in the text.

tion are taken from table 8 while average hours are projected using the rate of decline given by equation 3 . The ratio of business employment to total employment was maintained at its potential level in 1976. This assumption is probably a conservative projection of the portion of employment in the high-productivity business sector since the ratio of business employment to either total or total civilian employment generally rose in the past.

\section{Productivity}

The relationship between labor input and output in the business sector provides the basis for examining recent productivity behavior and estimating a potential output path for the economy. I start with the model relating output and weighted labor hours that I used previously for the whole economy ${ }^{19}$ and apply it here to the business sector. ${ }^{20} \mathrm{I}$ shall turn to the issue of capital adequacy below.

The basic model starts out with the proposition that weighted labor productivity grows exponentially along the potential path:

$$
\frac{\bar{Q}}{\bar{H}}=B e^{r t},
$$

19. Perry, "Labor Force Structure."

20. Nonresidential nonfarm business product equals total business product less product originating in farming and services of the housing stock. The scope is the same as in Edward F. Denison, Accounting for U.S. Economic Growth (Brookings Institution, 1974), and corresponds as closely as possible to the concept for labor input that is used in this paper. 
where $Q$ is output in the business sector, $r$ is the annual growth rate, $t$ is a time index, and the bars over variables indicate potential values. This can be modified to allow for a break in the growth trend:

$$
\frac{\bar{Q}}{\bar{H}}=B e^{\left(r_{1} t_{1}+r_{2} t_{2}\right)} .
$$

Cyclical deviations of productivity from its trend are expressed by

$$
\frac{\bar{Q}}{Q}=\left(\frac{\bar{H}}{H}\right)^{\beta},
$$

where $\beta>1$ if, as expected, productivity is higher the higher the level of actual hours or actual output relative to potential. Previous work has shown that some lags exist in this cyclical relation, and they are allowed for by modifying 6 to

or to

$$
\frac{\bar{H}}{\bar{H}}=\left(\frac{\bar{Q}}{Q}\right)^{\delta}\left[\frac{\bar{Q} / Q}{(\bar{Q} / Q)_{-1}}\right]^{p}
$$

$$
\frac{\bar{Q}}{Q}=\left(\frac{\bar{H}}{H}\right)^{\beta}\left[\frac{\bar{H} / H}{(\bar{H} / H)_{-1}}\right]^{\gamma} .
$$

Combining equations 5 and either $7 \mathrm{a}$ or $7 \mathrm{~b}$ to eliminate $\bar{Q}$ leads to the model used for statistical estimation.

\section{RECENT BEHAVIOR OF PRODUCTIVITY}

In 1974, at the start of the big recession, actual labor productivity in the business sector (in terms of conventional hours, not the weighted hours that are used throughout most of this analysis) fell 3.6 percent. This was not only a huge decline, but also the first one of any size in productivity since the war. Partly making up for this, productivity rose in the following year a substantial 1.8 percent despite the deepening recession. How much should the behavior of productivity in 1974 influence any assessment of the longer-run characteristics of the economy?

There is ample evidence that businessmen misjudged the severity of the downturn for a long time. They kept expanding employment long after output fell. And they continued to build up inventories long after final sales collapsed. Their optimism may have been encouraged by the government and the press, both of which continued to foster the impression that the economy was experiencing an "energy spasm" rather than a true reces- 
Table 10. Two Equations Relating Output and Labor Input, with and without Trend Break

\begin{tabular}{|c|c|c|c|c|}
\hline \multirow{2}{*}{$\begin{array}{l}\text { Coefficient, } \\
\text { regression statistic, and } \\
\text { structural characteristic }\end{array}$} & \multicolumn{2}{|c|}{ No trend break } & \multicolumn{2}{|c|}{ Trend break in 1969} \\
\hline & $\begin{array}{c}\text { Equation } \\
10.1^{\mathrm{a}}\end{array}$ & $\begin{array}{c}\text { Equation } \\
10.2^{\mathrm{b}}\end{array}$ & $\begin{array}{c}\text { Equation } \\
10.1^{\mathrm{a}}\end{array}$ & $\begin{array}{c}\text { Equation } \\
10.2^{\mathrm{b}}\end{array}$ \\
\hline \multicolumn{5}{|l|}{ Coefficient } \\
\hline$a_{0}$ & -4.938 & -8.102 & -5.279 & -8.113 \\
\hline$a_{1}$ & $\begin{array}{r}0.0163 \\
(20.5)\end{array}$ & $\begin{array}{r}0.0267 \\
(72.4)\end{array}$ & $\begin{array}{r}0.0179 \\
(13.5)\end{array}$ & $\begin{array}{r}0.0279 \\
(43.3)\end{array}$ \\
\hline$a_{2}$ & $\begin{array}{r}0.609 \\
(20.9)\end{array}$ & $\begin{array}{r}1.573 \\
(17.6)\end{array}$ & $\begin{array}{r}0.651 \\
(16.5)\end{array}$ & $\begin{array}{r}1.438 \\
(14.0)\end{array}$ \\
\hline$a_{3}$ & $\begin{array}{r}-0.087 \\
(-2.1)\end{array}$ & $\begin{array}{r}0.149 \\
(1.5)\end{array}$ & $\begin{array}{r}-0.093 \\
(-2.3)\end{array}$ & $\begin{array}{r}0.150 \\
(1.7)\end{array}$ \\
\hline$a_{4}$ & $\begin{array}{r}-0.0262 \\
(-3.6)\end{array}$ & $\begin{array}{r}-0.0514 \\
(-4.3)\end{array}$ & $\begin{array}{r}-0.0237 \\
(-3.3)\end{array}$ & $\begin{array}{r}-0.0421 \\
(-3.6)\end{array}$ \\
\hline$a_{5}$ & $\cdots$ & $\cdots$ & $\begin{array}{r}-0.0019 \\
(-1.5)\end{array}$ & $\begin{array}{r}-0.0042 \\
(-1.6)\end{array}$ \\
\hline \multicolumn{5}{|l|}{ Regression statistic } \\
\hline Standard error & 0.0064 & 0.0112 & 0.0062 & 0.0102 \\
\hline Durbin-Watson & 1.82 & 1.64 & 1.77 & 1.55 \\
\hline \multicolumn{5}{|c|}{ Structural characteristic (percent) } \\
\hline \multicolumn{5}{|c|}{$(d Q / Q) /(d H / H)$} \\
\hline Permanent & 1.64 & 1.57 & 1.54 & 1.44 \\
\hline First year & 1.92 & 1.72 & 1.79 & 1.59 \\
\hline \multicolumn{5}{|c|}{ Weighted productivity trend (percent) } \\
\hline Before 1969 & 2.68 & 2.67 & 2.75 & 2.79 \\
\hline Since 1969 & 2.68 & 2.67 & 2.46 & 2.37 \\
\hline \multicolumn{5}{|c|}{ Weighted productivity residual (actual minus predicted in percentage points) } \\
\hline 1976 & -0.6 & -1.1 & -0.3 & -0.4 \\
\hline 1975 & -0.4 & -1.2 & -0.3 & -0.9 \\
\hline 1973 & -0.1 & -0.2 & -0.2 & -0.6 \\
\hline
\end{tabular}

Source: Estimated from equations 10.1 and 10.2 given in notes $a$ and $b$ below. The period of estimation is $1954-76$.

a. Equation 10.1:

$$
\log \left(\frac{\bar{H}}{H}\right)_{t}=a_{0}+a_{1} T 54+a_{2} \log \left(\frac{\bar{H}}{Q}\right)_{t}+a_{3}\left[\log \left(\frac{\bar{H}}{Q}\right)_{t}-\log \left(\frac{H}{Q}\right)_{t-1}\right]+a_{4} D 74+a_{5} T 69
$$

where $H$ is weighted total hours, $\vec{H}$ is potential weighted hours, $Q$ is business-sector output, T54 and T69 are time-trend variables, and $D 74$ is a dummy variable whereby 1974 is ignored.

b. Equation 10.2:

$$
\log \left(\frac{Q}{\bar{H}}\right)_{t}=a_{0}+a_{1} T 54+a_{2} \log \left(\frac{H}{\bar{H}}\right)_{t}+a_{8}\left[\log \left(\frac{H}{\bar{H}}\right)_{t}-\log \left(\frac{H}{\bar{H}}\right)_{t-1}\right]+a_{4} D 74+a_{5} T 69
$$

sion. But regardless of whether these assessments were reasonable at the time, viewed in retrospect, they led to extremely unusual cyclical behavior 
in the economy. It seems best to acknowledge this, ignore 1974, and investigate recent productivity with the benefit of 1975 and 1976 developments. In the estimates of the model shown in table 10, this is accomplished by introducing a dummy variable, $D 74$, for 1974 .

The two estimating equations reported in table 10 use, alternatively, weighted hours (equation 10.1 from 5 and $7 \mathrm{a}$ ) and output (equation 10.2 from 5 and $7 \mathrm{~b}$ ) as dependent variables. The relation between the equation coefficients and the structural parameters of the model are as follows:

Equation 10.1

Equation 10.2

Weighted productivity growth trend

Without trend break

With trend break

Elasticity of output gap to input gap

First year

Permanent

$$
\begin{array}{ll}
a_{1} / a_{2} & a_{1} \\
\left(a_{1}+a_{5}\right) / a_{2} & a_{1}+a_{4}
\end{array}
$$

Constant Productivity Trend. To start with, consider the equations estimated with no break in the time trend over the 1954-76 period. The constant annual trend in weighted productivity is 2.68 percent and 2.67 percent in equations 10.1 and 10.2, respectively. Equation 10.1 predicts a permanent increase of 1.64 percent in output for each percent of gapclosing increase in weighted hours, or a weighted productivity bonus of 0.64 percent for each extra percent of weighted labor input. In the first year, the productivity bonus is 0.92 percent.

The productivity residuals from the equations that are displayed in the last three rows of table 10 all show that productivity was overestimated in recent years by the historic equations, but not by much. To put these errors in perspective, in table 11 the recent overpredictions from the equations that were estimated without a break in the productivity trend are compared with residuals from earlier years. The table gives the residual for all years in which it exceeded the root mean-square error (RMSE) of the equation for both forms. The residuals are shown as percentage shortfalls in actual weighted productivity from the predictions of the equation. The 1974 shortfall is huge in both forms of the equation. (It is not an estimated residual but the shortfall indicated by the dummy variable for that year.) The shortfalls in subsequent years are substantial compared with the RMSE of the equations, but so were the errors in seven of the 
Table 11. Large Residuals from Productivity Equations ${ }^{a}$

Percent

\begin{tabular}{ccc}
\hline Year & Equation 10.1 & Equation 10.2 \\
\hline 1956 & -1.0 & -1.8 \\
1957 & -1.2 & -1.9 \\
1958 & 1.1 & 1.4 \\
1960 & -0.6 & -1.3 \\
1969 & -0.7 & -1.2 \\
1971 & 0.6 & 1.1 \\
1972 & 0.8 & 1.5 \\
1974 & $-2.6^{\mathrm{b}}$ & $-5.1^{\mathrm{b}}$ \\
1975 & $\circ$ & -1.2 \\
1976 & -0.6 & -1.1 \\
\hline
\end{tabular}

Source: Equations with unbroken trend from table 10.

a. All residuals with absolute values larger than the root mean-square error of the residuals from the equations are shown.

b. 1974 was dummied out in the equations. The errors shown here are the errors implicit in the values of the dummy variable.

c. Under the stipulation of note $a$, the 1975 residual $(0.4)$ was too small to be included.

twenty years before 1974. By this standard, the present period is unusual, but not unusually unusual.

The recent performance of productivity may appear weaker than these shortfalls indicate because of the substantial positive residuals in 1971-72. Between 1972 and 1976, productivity adjusted for cyclical effects rose 2.5 percent less than expected from equation 10.2 and 1.4 percent less using equation 10.1. Even these swings are not extraordinary when compared with the swings between 1957 and 1958, 1958 and 1960, or 1969 and 1971. Of course, in those cases, we know that subsequent years brought the errors back to zero; we do not know that yet this time.

All in all, the equations estimated with a constant productivity trend can hardly be rejected on the basis of the economy's recent performance: 1974 was an unusual year that requires ad hoc explanations. But most of the productivity weakness that remained by 1976 is accounted for as the normal shortfall of productivity that accompanies high unemployment. This is especially true using equation 10.1. On the other hand, the constant productivity trend shown in table 10 is slower than the trend that would have been estimated with equations ending several years earlier. The possibility of a slowdown in the trend deserves further exploration.

Slowdown in Productivity Trend. The way to maximize one's concern about recent developments is to isolate the latest years. Equation 10.2 
estimated through 1973 shows a 3.1 percent shortfall in productivity when projected to 1976. But this procedure seems biased toward discovering a permanent productivity slowdown. It seemed better to explore the hypothesis of a trend break by allowing for one after a fairly recent year with a small prediction error. I chose 1969 to start a new trend and the resulting estimates are shown in the right half of table 10. The equation 10.1 form shows a 0.3 point slowdown after 1968 in the productivity trend, and the equation 10.2 form a 0.4 point slowdown. Compared to the equations without a trend break, these equations show faster productivity trends before 1969 and smaller cyclical productivity effects. The new equations have slightly lower standard errors than those without a trend break and show somewhat smaller prediction errors for 1975 and 1976. Equation 10.1 estimated with the broken trend shows not only small but stable residuals in these years and in 1973, suggesting that its trend estimate over that interval is close to the mark.

Possible Sources of a Trend Break. In view of the mixed evidence on recent productivity trends provided by the basic model, I looked for some alteration in the specification that would help resolve the issue. Like most other investigators, I suspect that a more fully specified model would include a role for the capital stock; but unlike some others, I did not choose to force the capital stock into the story by constraining it to enter the equations. I tried to find an explicit role for it in this relationship by adding, in turn, several versions of it to the basic model and estimating its effect. Expenditures for pollution abatement were subtracted from gross nonresidential stocks in the nonfarm business sector. Structures and equipment, and equipment separately, each for the total sector and for manufacturing separately, were tried as capital-stock measures, but each failed to enter the relationship significantly.

Another possible source of a slowdown in the productivity trend as I measure it would be that the weighting used for young workers overstates their contribution to output, perhaps because firms are investing in training them. Or more generally, the wage weights may simply be inaccurate proxies for relative productivities. However, neither the proportion of teenagers nor the proportion of adult males was successful as an additional explanatory variable. Since I could not settle to my own satisfaction the question of whether a trend break was appropriate, I used results both with and without the break to form two separate estimates of potential business output and potential GNP. 


\section{Potential GNP}

Potential business output, $\bar{Q}$, was generated by applying the trend productivity estimates from each form of equation 10.1 to the estimates of potential weighted manhours and anchoring potential output by equating it to actual output in the middle two quarters of 1955; this is the benchmark first established by Okun and widely accepted since. Potential GNP was then calculated by adding the difference between actual GNP and business output in each year. This procedure allows no change between actual and potential in either labor input or productivity for the nonbusiness part of GNP.

For projecting potential GNP, the same two productivity trends for the business sector were extended and combined with the projection of weighted manhours shown in table 9. As noted earlier, these projections assumed that the business sector would maintain its 1976 share of total potential employment. The remaining employment was assigned to the nonbusiness portion of GNP and the output that would be forthcoming there was projected using a relation estimated from the 1954-76 period:

$$
\begin{gathered}
\log Q N=0.163+\underset{(2.0)}{0.488} \log E N+\underset{0.0256754,}{(8.7)} \\
\text { Standard error }=0.0152 ; \text { Durbin-Watson }=1.678 ; \rho=0.60 .
\end{gathered}
$$

where $Q N$ and $E N$ are output and employment outside the business sector and $T 54$ is a time-trend dummy. The variables $Q N$ and $E N$ cover the government sector, in which there is no productivity growth by definition; the services of housing, which are produced without any labor; and agriculture, where productivity growth is very rapid. This is such a mixed bag that $I$ accepted this equation without question.

The two estimates of potential GNP are shown in table 12, together with the CEA's revised estimates and the previous official estimates. Potential I, which is based on the slower productivity trend starting in 1969, grows at a 3.9 percent annual rate between 1976 and the 1981 projection; potential II, based on the constant productivity trend, grows about 0.2 point a year faster. In this projection period, both measures grow at about the same rate as they did in the 1970-76 interval. In earlier years, potential I grew slightly faster than $3 \frac{1}{2}$ percent a year and potential II slightly slower. 
Table 12. Potential Gross National Product, 1954-76 and Projected, 1977-81

Billions of 1972 dollars

\begin{tabular}{|c|c|c|c|c|c|c|}
\hline \multirow[b]{2}{*}{ Year } & \multirow{2}{*}{$\begin{array}{c}\text { Potential I } \\
\text { (productivity } \\
\text { trend break } \\
\text { in 1969) }\end{array}$} & \multirow{2}{*}{$\begin{array}{c}\text { Potential II } \\
\text { (unbroken } \\
\text { productivity } \\
\text { trend) }\end{array}$} & \multicolumn{2}{|c|}{$\begin{array}{l}\text { Official estimates of } \\
\text { potential }\end{array}$} & \multicolumn{2}{|c|}{ GNP gap } \\
\hline & & & Revised & Previous & Potential I & Potential II \\
\hline 1954 & 633.0 & 633.3 & 629.7 & 634.4 & -19.3 & -19.6 \\
\hline 1955 & 654.8 & 654.8 & 651.4 & 656.6 & 0.0 & 0.0 \\
\hline 1956 & 674.3 & 673.9 & 673.9 & 679.6 & -5.5 & -5.1 \\
\hline 1957 & 697.6 & 696.9 & 697.2 & 703.4 & -16.7 & -16.0 \\
\hline 1958 & 722.2 & 721.0 & 721.3 & 728.0 & -42.6 & -41.5 \\
\hline 1959 & 749.5 & 748.0 & 746.2 & 753.5 & -29.1 & -27.6 \\
\hline 1960 & 777.2 & 775.1 & 771.9 & 779.9 & -40.4 & -38.3 \\
\hline 1961 & 804.7 & 802.2 & 798.6 & 807.1 & -49.4 & -46.9 \\
\hline 1962 & 832.9 & 829.9 & 826.4 & 835.4 & -33.8 & -30.8 \\
\hline 1963 & 859.8 & 856.3 & 857.1 & 865.9 & -29.1 & -25.6 \\
\hline 1964 & 890.0 & 885.7 & 890.3 & 898.4 & -15.5 & -11.3 \\
\hline 1965 & 922.7 & 918.0 & 925.0 & 932.1 & 3.2 & 7.9 \\
\hline 1966 & 956.0 & 950.7 & 960.8 & 967.0 & 25.0 & 30.3 \\
\hline 1967 & 988.8 & 982.7 & 996.3 & $1,003.3$ & 18.9 & 25.0 \\
\hline 1968 & $1,021.9$ & $1,015.8$ & $1,031.7$ & $1,040.9$ & 30.0 & 36.0 \\
\hline 1969 & $1,055.9$ & $1,050.6$ & $1,068.3$ & $1,081.6$ & 23.0 & 28.2 \\
\hline 1970 & $1,095.4$ & $1,091.7$ & $1,106.2$ & $1,124.9$ & -20.1 & -16.4 \\
\hline 1971 & $1,138.1$ & $1,136.0$ & $1,145.5$ & $1,169.9$ & -30.6 & -28.5 \\
\hline 1972 & $1,185.1$ & $1,184.8$ & $1,186.1$ & $1,216.7$ & -14.0 & -13.7 \\
\hline 1973 & $1,231.3$ & $1,233.1$ & $1,228.2$ & $1,265.4$ & 3.7 & 1.9 \\
\hline 1974 & $1,279.6$ & $1,283.6$ & $1,271.7$ & $1,315.9$ & -65.6 & -69.6 \\
\hline 1975 & $1,328.5$ & $1,334.9$ & $1,316.9$ & $1,368.6$ & -136.7 & -143.2 \\
\hline 1976 & $1,379.2$ & $1,388.1$ & $1,363.6$ & $1,421.2$ & -114.6 & -123.5 \\
\hline 1977 & $1,436.7$ & $1,448.5$ & $1,412.0$ & $\ldots$ & $\ldots$ & $\ldots$ \\
\hline 1978 & $1,492.3$ & $1,507.0$ & $1,462.1$ & $\ldots$ & $\ldots$ & $\ldots$ \\
\hline 1979 & $1,550.4$ & $1,568.3$ & $1,513.9$ & $\ldots$ & $\ldots$ & $\ldots$ \\
\hline 1980 & $1,607.9$ & $1,629.3$ & $1,567.7$ & $\ldots$ & $\ldots$ & $\ldots$ \\
\hline 1981 & $1,668.3$ & $1,693.3$ & $\ldots$ & $\ldots$ & $\ldots$ & $\ldots$ \\
\hline
\end{tabular}

Sources: Potentials I and II are derived from table 10 equations and text equation 8; official estimates are those of the Council of Economic Advisers from Economic Report of the President, January 1977, p. 54, except for 1977-81, which are from Peter K. Clark, "A New Estimate of Potential GNP" (Council of Economic Advisers, January 27, 1977; processed); GNP gap is calculated by subtracting potential I or II, in the first two columns, from the corresponding actual GNP from Economic Report, 1977, p. 54.

\section{OKUN'S LAW}

How well do Okun's law and the new estimates of potential GNP stack up against one another? Table 13 shows several equations relating gaps in output and in conventional unemployment rates. The latter are not the 
Table 13. Okun's Law Estimates Using Potential Gross National Product I and II ${ }^{\mathrm{a}}$

\begin{tabular}{|c|c|c|c|c|c|c|}
\hline \multirow[b]{2}{*}{$\begin{array}{c}\text { Equation and } \\
\text { potential }\end{array}$} & \multicolumn{3}{|c|}{ Coefficient } & \multicolumn{2}{|c|}{ Regression statistic } & \multirow{2}{*}{$\begin{array}{l}\text { Okun's } \\
\text { law co- } \\
\text { efficient }\end{array}$} \\
\hline & $a_{1}$ & 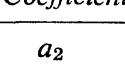 & $a_{3}$ & $\begin{array}{l}\text { Standard } \\
\text { error }\end{array}$ & $\begin{array}{l}\text { Durbin- } \\
\text { Watson }\end{array}$ & \\
\hline \multicolumn{7}{|l|}{ Equation $13.1^{\mathrm{b}}$} \\
\hline Potential I & $\begin{array}{r}2.88 \\
(21.0)\end{array}$ & $\begin{array}{l}0.16 \\
(1.1)\end{array}$ & $\begin{array}{r}0.031 \\
(4.3)\end{array}$ & 0.0072 & 1.4 & 3.04 \\
\hline Potential II & $\begin{array}{r}2.94 \\
(18.3)\end{array}$ & $\begin{array}{r}0.14 \\
(0.8)\end{array}$ & $\begin{array}{r}0.034 \\
(4.0)\end{array}$ & 0.0085 & 1.1 & 3.08 \\
\hline \multicolumn{7}{|l|}{ Equation $13.2^{\mathrm{c}}$} \\
\hline Potential I & $\begin{array}{l}0.328 \\
(28.3)\end{array}$ & $\begin{array}{l}-0.010 \\
(-4.2)\end{array}$ & $\begin{array}{l}\cdots \\
\ldots\end{array}$ & 0.00238 & 1.6 & 3.05 \\
\hline Potential II & $\begin{array}{r}0.319 \\
(25.5)\end{array}$ & $\begin{array}{l}-0.010 \\
(-3.8)\end{array}$ & $\ldots$ & 0.00265 & 1.5 & 3.13 \\
\hline
\end{tabular}

Source: Based on data in tables 6 and 12.

a. The numbers in parentheses are $t$ statistics.

b. Equation 13.1: $\frac{\bar{Q}-Q}{Q}=a_{1}(u-\bar{u})+a_{2}(u-\bar{u})_{-1}+a_{3} D 74$,

where $Q$ is real GNP and $u$ the conventional unemployment rate; bars over variables indicate potential values; and $D 74$ is a dummy variable for the year 1974 . All equations were estimated with annual data over 1954-76.

c. Equation 13.2: $(u-\bar{u})=a_{1}\left(\frac{\bar{Q}-Q}{Q}\right)+a_{2} D 74$.

difference between actual unemployment and 4.0 percent, but those unemployment gaps measured against the changing unemployment rate that defines potential as shown in table 6 . The equations use the output gap and unemployment gap alternatively as dependent variables. When the lagged unemployment gaps are used as an added independent variable, their coefficients are only about equal to their standard errors. The year 1974 is dummied out on the grounds described earlier. The question usually asked of this relation is how much unemployment will change for a given change in the GNP gap. In the present estimates, the answer is much the same no matter the form of the equation in the table, although the equations in the bottom half of the table are more appropriate in principle. Compared with Okun's original estimate that a 3.2 percent output gap was associated with one point of unemployment, the present estimates of the Okun's law coefficient are 3.05 using potential I and 3.13 using potential II.

Both the intervals 1969-76 and 1973-76 are tracked reasonably well with either potential estimate and its corresponding Okun's law coefficient. 
In the longer interval, real GNP rose 17.2 percent compared with 30.6 percent for potential I and 32.1 percent for potential II, thus opening up output gaps of 11.2 and 12.6 percent, respectively. Okun's law predicts a widening of 3.7 points in the unemployment rate gap using I and one of 3.9 points using II; the actual rise was 3.7 points. Between 1973 and 1976, the predicted rise in the gap was 3.0 and 3.1 points, respectively, for potentials I and II; the actual rise was 2.8 points. Starting from a year like 1971 , with the large productivity residual noted earlier, the relation does not perform as well. The unemployment gap widens by 1.5 points compared with predictions of 2.1 points from potential I and 2.3 points from potential II. I interpret these results as generally supporting the potential estimates made here, and favoring slightly the estimates of potential I.

The GNP gap for 1976 can be decomposed into several parts. Closing the unemployment rate gap of 2.8 points would increase total employment by 6.0 percent while expanding the labor force by 2.9 percent. Employment in the business sector would rise 8.6 percent and average hours would increase 1.2 percent, for a total rise of 9.9 percent in (unweighted) hours. Together with a 2.6 percent improvement in productivity in the business sector conventionally measured, these increases would close the 12.3 percent gap in 1976 business output estimated using potential I. With potential II, productivity in the business sector would be 3.5 percent higher than it was in fact, closing the 13.3 percent business output gap in that estimate.

\section{POTENTIAL ESTIMATES COMPARED}

The new CEA estimates of the 1976 level of potential appear somewhat pessimistic, although they represent a clear improvement over the former official projections, which were really made obsolete by last year's revision of benchmarks in the GNP accounts. In shifting to a 1972 base for the price deflator, the annual growth rate of real GNP was reduced by about 0.2 percentage point. This can account for a large part of the apparently excessive growth of the old series. Another important part of the difference must arise from the redefinition of the unemployment rate at potential from the old 4 percent rate to the 4.9 percent for 1976 in the new estimates of the Council of Economic Advisers.

About half of the difference between the 1976 estimate of potential I and CEA's revised one reflects the difference in the benchmark year, 1955. 
If the CEA series is adjusted to the 1955 level in mine, their 1976 potential becomes $\$ 1,370.7$ billion, or only 0.6 percent below potential I and 1.2 percent below potential II. My estimates lend no support to the pessimistic assessment offered by CEA that their own estimates of potential may be $\$ 30$ billion too high based on an alternative reading of recent productivity developments. ${ }^{21}$ While their estimate of the 1976 gap is $\$ 99$ billion and mine is $\$ 115$ billion to $\$ 124$ billion, their pessimistic assessment implies a gap of only $\$ 69$ billion.

Future Potential. An even more important difference with CEA comes in projecting growth rates of potential. From 1976 to 1980, CEA projects a growth rate of $3 \frac{1}{2}$ percent a year, while the annual growth rate of potential I is 3.88 percent and that of potential II, 4.05 percent. Even the more conservative projection of potential I for 1980 is some $\$ 40$ billion (1972 prices) above CEA's.

The slowdown in the growth of the capital stock and the impact of higher energy prices are two reasons given by the CEA for its pessimistic estimates of recent and prospective potential GNP. Since the effect of the capital stock on potential productivity is so hard to identify, it is impossible to evaluate this concern. Modest deviations from past growth rates in capital-output ratios may well have only negligible effects on potential productivity. The capital stock can indeed pose a barrier to reaching potential if it turns out that industrial capacity is inadequate to meet future demands and thus inflationary price pressures develop while labor markets are still slack. But that is a different issue and one that lies well beyond the scope of this paper. ${ }^{22}$

I find it hard to see how high energy prices can affect productivity and potential output much. Energy is one input into production processes. Eventually some adjustment of production processes to conserve on energy is likely. But the effect on labor productivity can hardly be measurable. As Okun has calculated, on generous assumptions about how much labor could be substituted for energy in response to the price rise of 1974, the productivity dent could not exceed $\$ 3$ billion, or 0.2 percent. ${ }^{23}$

My own projections of a nearly 4 percent rate of potential growth in

21. Economic Report of the President, January 1977, p. 55.

22. A recent analysis of this problem is made by Barry Bosworth in "Capacity Creation in Basic-Materials Industries," BPEA, 2:1976, pp. 297-341.

23. Arthur M. Okun, "Unemployment and Output in 1974," $B P E A, 2: 1974$, p. 503. 
the coming years rest on the demographic fact of a maturing labor force and what appear to me reasonably conservative projections of other parts of the puzzle. Table 14 summarizes the ingredients underlying the projections of the potential I path and compares them with past intervals. Growth of both the potential labor force and employment slows to a 2.1 percent annual rate in the 1976-81 period, a little slower than in the 1965-70 interval and substantially slower than over 1970-76. Growth in business employment is sharply lower than in 1970-76 as the reduction in the armed forces is not assumed to continue. Average hours decline at the same rate as during 1970-76, an assumption I find hard to justify but also hard to fault. The one thing we know about-demographic shiftscould bring with it a slower decline. The favorable development is in output per (unweighted) hour. The changing employment mix that was projected in table 8 results in a much smaller difference between conventionally measured and weighted productivity growth than has been true over the past decade.

Given the estimates based on potential I, reducing unemployment to 5 percent by reaching potential output for the year 1981 would require a sustained, strong expansion. Starting from 1976, actual employment would have to rise by an average of 3.2 percent a year and real GNP would have to grow at an average rate of 5.7 percent a year. Allowing for a gradual deceleration of the rate of economic expansion as potential is approached, actual growth in GNP somewhat above 6.0 percent would be needed over most of the period. Should the path of potential II turn out to be the right description of the future, these same GNP growth rates would leave unemployment at about 51/2 percent in 1981.

There is no precedent in postwar U.S. economic performance for the sustained high rates of expansion projected here. The expansion of 196166 comes closest. However, it started with a smaller GNP gap, and potential was growing less rapidly than now projected. Furthermore, that expansion began in a period without inflation. It remains an open question whether, in coming years, inflation will deter policymakers from pursuing the rapid increases in GNP that would make 1981 a year of 5 percent unemployment. The answer to that question will depend on many things: how inflation responds to the expansion; how successful the government is with specific anti-inflationary policies; how much the price level is affected by an energy program and other economic developments or policies that are largely unrelated to the level of unemployment or the 
Table 14. Profile of Changes in the Economy at Potential, Selected Intervals, 1955-81

Annual rate of growth in percent

\begin{tabular}{lccccc}
\hline Sector and economic measure & $1955-60$ & $1960-65$ & $1965-70$ & $1970-76$ & $\begin{array}{c}\text { Projected } \\
1976-81\end{array}$ \\
\hline $\begin{array}{l}\text { Total economy } \\
\text { Labor force }\end{array}$ & 1.01 & 1.29 & 2.17 & 2.39 & 2.08 \\
Employment & 0.97 & 1.23 & 2.14 & 2.31 & 2.07 \\
Real GNP & 3.49 & 3.49 & 3.53 & 3.91 & 3.88 \\
Business sector & & & & & \\
Employment & 1.21 & 1.11 & 2.30 & 2.87 & 2.07 \\
Total hours & 0.95 & 0.84 & 1.41 & 2.41 & 1.53 \\
Output & 3.62 & 3.42 & 3.64 & 4.34 & 3.92 \\
Output per hour & 2.65 & 2.56 & 2.19 & 1.96 & 2.35 \\
Output per weighted hour & 2.79 & 2.79 & 2.67 & 2.48 & 2.49 \\
\hline
\end{tabular}

Source: Author's estimates based on potential I path.

rate of expansion; and how policymakers balance unemployment targets against price stability or other economic goals. Also, if policies to provide public jobs directly are pursued vigorously even after unemployment is substantially reduced from present levels, then the historical link between unemployment and GNP may be stretched, producing a somewhat greater decline in unemployment per dollar of GNP than has been estimated here.

A path for GNP that even approached the one mapped here for achieving 5 percent unemployment by 1981 would require a large expansion of the capital stock in coming years. And achieving this expansion would mean a rapid rise in business investment. That, in turn, would help spur the increase in aggregate demand required and would permit, and eventually require, a reduction in the present full-employment deficit of the federal budget.

\section{A P PENDIX}

\section{Alternative Participation Equations}

TABLE A-1 presents the estimates of cyclical and trend effects on participation rates from several equations. Cyclical effects are expressed by the 
sum of the estimated coefficients on the weighted unemployment rate. Trend effects are expressed by the sum of the time-trend coefficients and thus give the estimated trend growth in participation rates for recent years. The equations are all of the form of equation 1 in the text. The estimates differ according to the period over which the equations were estimated and the year in which the time trends start.

Table A-1. Effects on Labor Force Participation Rates of Equations with Alternative Estimation Periods and Time Trends, by Age-Sex Groups

\begin{tabular}{lllllllll}
\hline \multirow{2}{*}{$\begin{array}{c}\text { Effect, } \\
\text { period of estimation, } \\
\text { and starting year of } \begin{array}{c}\text { Age group } \\
\text { time trend }\end{array}\end{array}$} & $16-19$ & $20-24$ & $25-34$ & $35-44$ & $45-54$ & $55-64$ & $\begin{array}{c}65 \text { and } \\
\text { over }\end{array}$ \\
\hline
\end{tabular}

Cyclical effect (sum of unemployment coefficients)

Males

1949-76

1967

1970

1954-76

1967

1970

1949-73

1967

1970

$$
\begin{array}{rrrrrrr}
-2.99 & -1.79 \mathrm{a} & -0.12 & \ldots & \ldots & \ldots & -2.06^{\mathrm{a}} \\
-3.78 & -1.79^{\mathrm{a}} & -0.11 & \ldots & \ldots & \ldots & -2.06^{\mathrm{a}} \\
& & & & & & \\
-2.95 & -1.28 & -0.07 & \ldots & \ldots & \ldots & -2.89 \\
-4.31 & -1.59 & \ldots & \ldots & \ldots & \ldots & -2.20 \\
& & & & & & \\
-3.39 & -2.00^{\mathrm{a}} & -0.12 & \ldots & \ldots & \ldots & -2.24 \\
-3.95 & -2.00^{\mathrm{a}} & -0.11 & \ldots & \ldots & \ldots & -1.24
\end{array}
$$

Trend effect (sum of time-trend coefficients) ${ }^{\mathrm{b}}$

1949-76

1967

1970

1954-76

1967

1970

1949-73

1967

1970
1.18

2.35

$$
\begin{array}{lllll}
\ldots & -0.19 & -0.17 & -0.40 & -1.37
\end{array}
$$$$
\begin{array}{lllll}
\ldots & -0.21 & -0.23 & -0.51 & -1.78
\end{array}
$$

1.30

$\begin{array}{llllll}0.10 & -0.18 & -0.16 & -0.38 & -1.30 & -2.04\end{array}$

2.65

$\begin{array}{llllll}0.46 & -0.25 & -0.17 & -0.50 & -1.69 & -3.11\end{array}$

$\begin{array}{lllllll}0.49 & \ldots & -0.23 & -0.12 & -0.35 & -1.20 & -2.13\end{array}$

1.78

... -0.30

$$
\begin{array}{llll}
-0.21 & -0.47 & -1.77 & -3.87
\end{array}
$$

\section{Standard errors ${ }^{\mathrm{b}}$}

$1949-76$
1967
1970
$1954-76$
1967
1970
$1949-73$
1967
1970

$\begin{array}{lllllll}2.8 & 1.4 & 0.3 & 0.2 & 0.2 & 0.7 & 2.5 \\ 2.6 & 1.4 & 0.3 & 0.1 & 0.2 & 0.7 & 2.5 \\ & & & & & & \\ 2.9 & 0.9 & 0.2 & 0.2 & 0.2 & 0.7 & 2.5 \\ 2.6 & 0.9 & 0.2 & 0.1 & 0.2 & 0.5 & 2.6 \\ & & & & & & \\ 2.7 & 1.4 & 0.3 & 0.2 & 0.2 & 0.7 & 2.5 \\ 2.7 & 1.4 & 0.3 & 0.1 & 0.2 & 0.7 & 2.6\end{array}$


Table A-1 (Continued)

\begin{tabular}{|c|c|c|c|c|c|c|c|}
\hline \multirow{2}{*}{$\begin{array}{l}\text { Effect, } \\
\text { period of estimation, } \\
\text { and starting year of } \\
\text { time trend }\end{array}$} & \multicolumn{7}{|c|}{ Age group } \\
\hline & $16-19$ & $20-24$ & $25-34$ & $35-44$ & $45-54$ & $55-64$ & $\begin{array}{c}65 \text { and } \\
\text { over }\end{array}$ \\
\hline & \multicolumn{7}{|c|}{ Females } \\
\hline \multicolumn{8}{|c|}{ Cyclical effect (sum of unemployment coefficients) } \\
\hline \multicolumn{8}{|c|}{$1949-76$} \\
\hline 1967 & -3.34 & -2.42 & -2.20 & -1.81 & -0.99 & -0.94 & $\ldots$ \\
\hline 1970 & -4.46 & -2.05 & -2.72 & -1.92 & -0.95 & -0.83 & ... \\
\hline \multicolumn{8}{|l|}{$1954-76$} \\
\hline 1967 & -3.32 & -2.65 & -1.97 & -1.67 & -0.51 & -0.89 & ... \\
\hline 1970 & -4.63 & -3.32 & -2.58 & -1.93 & -0.43 & -0.56 & ... \\
\hline \multicolumn{8}{|l|}{$1949-73$} \\
\hline 1967 & -3.77 & -2.88 & -3.28 & -2.22 & -1.13 & -1.18 & $\ldots$ \\
\hline 1970 & -4.69 & -2.20 & -3.20 & -2.24 & -1.10 & -1.13 & ... \\
\hline \multicolumn{8}{|c|}{ Trend effect (sum of time-trend coefficients) ${ }^{\mathrm{b}}$} \\
\hline \multicolumn{8}{|l|}{$1949-76$} \\
\hline 1967 & 3.09 & 2.89 & 4.12 & 2.33 & 0.49 & -0.44 & -2.36 \\
\hline 1970 & 4.57 & 3.26 & 5.25 & 2.63 & 0.16 & -0.94 & -3.49 \\
\hline \multicolumn{8}{|l|}{$1954-76$} \\
\hline 1967 & 3.13 & 2.87 & 4.13 & 2.43 & 0.45 & -0.27 & -2.27 \\
\hline 1970 & 4.55 & 3.69 & 5.10 & 2.88 & 0.05 & -1.14 & -2.97 \\
\hline \multicolumn{8}{|l|}{ 1949-73 } \\
\hline 1967 & 2.76 & 2.70 & 3.61 & 1.83 & 0.30 & -0.60 & -2.26 \\
\hline 1970 & 4.61 & 3.10 & 4.75 & 1.89 & 0.38 & -1.55 & -3.53 \\
\hline \multicolumn{8}{|l|}{ Standard errors ${ }^{\mathrm{b}}$} \\
\hline \multicolumn{8}{|l|}{$1949-76$} \\
\hline 1967 & 2.6 & 1.7 & 2.0 & 1.4 & 1.8 & 1.9 & 4.3 \\
\hline 1970 & 2.7 & 2.0 & 2.1 & 1.4 & 1.8 & 2.0 & 4.4 \\
\hline \multicolumn{8}{|l|}{$1954-76$} \\
\hline 1967 & 2.8 & 1.5 & 1.7 & 1.2 & 1.4 & 1.6 & 3.3 \\
\hline 1970 & 2.9 & 1.6 & 1.8 & 1.3 & 1.3 & 1.5 & 3.0 \\
\hline \multicolumn{8}{|l|}{$1949-73$} \\
\hline 1967 & 2.7 & 1.7 & 1.7 & 1.2 & 1.9 & 2.0 & 4.6 \\
\hline 1970 & 2.9 & 2.1 & 2.1 & 1.3 & 1.9 & 2.0 & 4.6 \\
\hline
\end{tabular}

Source: Estimated by author.

a. Neither time trend appeared in this equation.

b. The results were multiplied by 100 . 


\section{Comments and Discussion}

Michael L. Wachter: George Perry has updated his 1971 paper on potential output, concluding that the traditional macroeconomic supply model is still reliable and that the economy has the potential for fullspeed-ahead economic growth between 1977 and 1981. Methodologically, Perry presents a viable, coherent, and consistent model of what I view to be the "optimistic"-perhaps highly optimistic-story of current and near-term supply developments. My approach to the supply side interprets the data in a different framework and arrives at significantly lower estimates of potential output. In this comment I utilize my framework for a critique of Perry's methodology and to indicate the various areas in which he may be overstating potential output.

Most of my comments will be directed at the labor supply equations, which are, as Perry notes, a pivotal component of his potential output series. I have long been surprised that Perry, having devised the initial adjustment of the unemployment rate for changes in the labor force mix, would remain a proponent of the large GNP gap. The old measure of the gap was built on the foundation of a 4 percent equilibrium unemployment rate, and the Perry index clearly exhibits a nonaccelerating inflation rate of unemployment considerably higher than 4 percent. If the benchmark, noninflationary rate is high, where are the extra unutilized resources necessary to generate a large GNP gap? Part of the answer to this problem is that Perry has hidden away a large group of "discouraged workers." These workers will flood into the labor market, at unchanged real and nominal wage rates, to provide the upward ratchet for potential output. Indeed, for some age-sex groups, the coefficients of table 1 predicting new additions to the labor force per net job created suggest a deluge of new entrants or reentrants. 
My own results suggest a different interpretation of the participation rates; and, Perry's new calculations notwithstanding, I believe that the evidence for a sizable discouraged-worker component is shaky. Perry's significant and quantitatively important unemployment coefficient in table 1 is highly dependent on his specification of the participation model. In particular, Perry's ability to discount the inflation variable as explaining participation rather than unemployment is affected by his use of a splittrend variable broken in 1967 or 1970 . My earlier results suggested that the discouraged-worker model began to generate perverse predictions in 1969-70, a period in which unemployment increased and participation rates rose significantly. The split trend in 1967 or 1970 allows Perry to relabel this seemingly perverse rise in participation rates as part of the new sociological attitudes of younger women toward market work. Since inflation rates also accelerated after 1970, these two variables are highly collinear. In straight horse races between unemployment and inflation rates, without the broken trend, the latter does considerably better than it does in the results reported in table 4.

Using the inflation variable in place of the discouraged-worker effect suggests several changes in the interpretation of the potential-output measure. First, unless the inflation rate continues to trend upward, most of the cyclically sensitive or "inflation-sensitive" workers are already in the labor force. Although the labor force will continue to grow rapidly over the next few years because of underlying population growth in the relevant age groups, there should not be a new "bonus" of newly encouraged workers as unemployment falls to its noninflationary level.

Second, the implications of the presence of inflation-sensitive workers are different from those of discouraged workers. The latter are a pure bonus in that they enter the labor force regardless of wage and price movements. The former are a part of the supply picture only at a cost in inflation. An exogenous potential output, measured at zero inflation-in the Perry tradition-would exclude these workers.

Third, although the empirical results are ambiguous, many cyclically sensitive or inflation-sensitive workers are likely to be only temporary additions to the labor force at full employment with 6 percent inflation. As Mincer originally warned us, the discouraged-worker effect may be measuring the "timing" of part-time workers. If some workers want to work part of the time, they have an obvious incentive to coordinate their entry into the labor market and their employment with periods of low 
unemployment rates (and high discounted real wages). Empirically, there is considerable evidence of a large contingent of workers who work part of the time and frequently move into and out of the labor force. The better or more rational the timing of these workers, the greater the appearance of a large "discouraged worker" contingent. If the economy manages to stay at full employment, these workers will eventually drift out of the labor force, reducing potential output. This timing effect may also be relevant to inflation-sensitive workers to the extent that they are responding to short-term money illusion. I do not believe that these workers are all temporary additions, but it is highly optimistic to believe, at the other extreme, that they are all permanent additions.

In short, I would favor excluding the discouraged-worker contingent from an exogenous measure of potential output. It is unclear that these workers are cyclically rather than inflation sensitive and that they will remain in the labor force if the economy is at full employment for any extended period of time. Removing this group would considerably reduce Perry's potential output measure for 1976.

An additional issue in the equations for labor force participation concerns the role of relative wages. Here a data problem is the main culprit in Perry's insignificant and incorrect coefficients. Although Perry uses the aggregate wage as the basis for the $w / w^{*}$ construct, the desired variable is an unavailable age-specific wage rate. Apparently, it is largely after 1970 that age-specific and aggregate wages diverge in any meaningful way. In particular, aggregate real wages increase dramatically in 1971 and 1972, but not those for young workers. The sharp increase in the relative percentage of young workers reduced their relative wage as it increased their relative unemployment rates. My argument has been that the increase in participation rates for young females and the concomitant decrease in fertility rates is related to their (relatively) adverse labor market experiences. This has been confirmed by the data of the 1970s although it does not appear in the aggregate data on wage rates.

Fluctuations in the labor force due to changes in relative wages among cohorts are intermediate-run swings that are similar in some respects to the Kuznets cycle. Hence they are not quantitatively important for Perry's short-run prognosis. They do have significant implications, however, for extrapolating the growth of the labor force into the 1980s. In particular, these models suggest that labor force growth would be considerably less robust than is suggested by using the Perry model to forecast the 1980 s. 
Perry's trend variable mechanically extrapolates into the future something like the very rapid recent increases in participation rates among young females. In the context of an overall demographic model, this implies a further significant drop in fertility and school-enrollment rates for young people. I believe that this outcome is unlikely. As the current babyboom cohort ages, the high level of participation rates for young women today is likely to be reflected in higher participation rates for older women in the future. It is much more problematical, however, to predict that the next cohort of young women will have an even higher participation rate than the current cohort.

Again, these considerations suggest that Perry's labor force projections are too high. In addition, they suggest that potential output should not be treated as an exogenous variable. In the short and long runs, the supply constraint of society is responsive to fluctuations in economic variables.

Besides overstating labor force growth, Perry may, I believe, overstate the noninflationary rates of employment for the different age-sex groups. My comments here have been based on the model I outlined in a previous paper (BPEA, 1:1976), and they suggest an increase in the steady-state unemployment rate of approximately one-half percent (on aggregate unemployment) beyond that suggested by Perry. In addition, if that model is correct, Perry's wage-weighting scheme is also too optimistic. The largest cohorts will suffer an adverse relative-wage adjustment. Hence, Perry is always giving the largest groups too high a relative wage rate. This is especially a problem for near-term projections as the boom-babies age and enter the prime-age categories.

In his discussion of productivity Perry seems appropriately cautious on the question of the long-term productivity trend. This remains an area of substantial uncertainty. His productivity estimates, however, specifically ignore the potential problems that he identifies. Of particular concern to me is the continuing shift between unemployment rates and capacity utilization rates as measured by either the Wharton or the Federal Reserve Board index. In all cases, the shift indicates that the noninflationary unemployment rate may be above 5.5 percent (at least in the short run) or that the capital-stock numbers are overstated, or both. The quality of the data on capacity and capital stock is open to some question; however, it seems unlikely that errors in these variables would make this problem disappear entirely. In other words, Perry's estimates represent the upper bound of the supply constraints on the capital stock. 
In general, Perry is consistent in developing an upper bound for potential output. His calculations may well turn out to be correct, but a growth policy based on his supply series has major inflationary risks.

Otto Eckstein: George Perry's paper carefully updates his earlier study of the full-employment labor force and potential GNP, and explores econometrically the changing participation rates for the major groups in the population. He confirms that the participation rate of women has accelerated and is rooted in sociological fundamentals. He also finds a break in the time trends for adult men, whose participation rate is falling. While he offers little explanation of this phenomenon, one can easily turn to such factors as changes in the social security, unemployment insurance, and welfare systems, early retirement provisions in collective bargaining agreements, perhaps the regional distribution of older workers as compared to changing job opportunities, perhaps the increasing competition from women for certain categories of jobs, perhaps even a decline in the work ethic. As medical knowledge of heart disease and other degenerative diseases improves, we may live to regret the policy decisions that have lowered the retirement age and that have hurt the participation rates of male workers increasingly from age 25 on.

But there are two other important questions raised more directly by the Perry paper: First, should we accept the Perry estimate of a potential growth rate near 4 percent for the next five years, contrary to the conclusions of various other studies including those by Roger Brinner for DRI and by the Council of Economic Advisers in their last annual report? Second, for the kind of economy in which we now live, what really is the pertinence of the concept of potential output? I shall deal with these briefly in turn.

Perry concludes that the probable annual growth rate for potential GNP for the period $1976-81$ is 3.9 percent. This is roughly half a point higher than the CEA or DRI conclusions. When Brookings disagrees with the CEA and DRI, we had better take a look at the reasons.

The table below juxtaposes the components of the growth of potential GNP for the Perry (Brookings) and Brinner (DRI) studies. It shows the source of difference between the two projections. There is no substantive disagreement in the analysis of the growth in the full-employment labor force or in potential output for the historical period, although there are differences in the underlying methods. Brinner uses somewhat different 
breaks in the age composition and uses unweighted unemployment rates. His formulas for the cyclical element in participation rates are of the standard type, as are Perry's. Differences in definition and slightly different periods lead to differences in the growth rates of 0.1 point. For the periods of the individual studies shown in the table, the potential growth rates for the labor force are very close, although over the specific 197681 interval that Perry reports on, the Brinner projection would show slightly lower growth. However, the forecast horizon reveals the impact of the different methodologies plus alternative assessments of the outlook for productivity growth.

\begin{tabular}{|c|c|c|c|c|}
\hline \multirow[b]{2}{*}{ Component of growth } & \multicolumn{2}{|c|}{ Perry study } & \multicolumn{2}{|c|}{ Brinner study } \\
\hline & $1960-76$ & $1976-81$ & 1963-73 & $1973-80$ \\
\hline & \multicolumn{4}{|c|}{ Compound annual rates of growth } \\
\hline Labor force & 2.0 & 2.1 & 2.1 & 2.1 \\
\hline Real GNP & 3.7 & 3.9 & 3.8 & 3.4 \\
\hline Implicit GNP per person & 1.6 & 1.8 & $\ldots$ & $\ldots$ \\
\hline Total inputs & $\ldots$ & $\ldots$ & 2.8 & 2.3 \\
\hline Total factor productivity & $\ldots$ & $\ldots$ & 1.0 & 1.0 \\
\hline
\end{tabular}

Perry bases his analysis on the labor-productivity trend, while Brinner uses the aggregate-production-function approach. There may have been a time when the two approaches came to about the same conclusion, and both are of long standing. The projections in a 1960 study for the Joint Economic Committee, by James W. Knowles, The Potential Economic Growth in the United States, used a Cobb-Douglas production function. This was one of the first analyses of the problem, and its projections proved to be correct for the 1960s. While the two approaches may have given similar answers in the past, they cannot be expected to do so now. Growth of the capital stock has slowed severely-from 3.9 to 2.9 percent-because of the liquidity crisis in 1973-74 and the subsequent deep recession. With the Cobb-Douglas factor-share weights, this decline cuts the growth of potential output by a third of a point.

Could such a dramatic reduction in the growth of capital have no impact on the growth of potential? Only a strange economic theory would reach that conclusion. Perhaps technology is really so disembodied that the Cobb-Douglas function inadequately represents the role of capital. But that there be no relation between capital and output is impossible! And yet that is what an analysis of potential output based on nothing but labor productivity and labor supply would require. 
Furthermore, the labor-productivity approach breaks down statistically for recent years, as Perry shows. He finds a break in the time trends and employs a lower time trend beginning with 1969. That trend creates a slowdown of 0.3 to 0.4 percent from that date onward. Further, it is necessary to dummy out 1974, which admittedly was a very strange year for productivity because business was operating on a false set of expectations. But with 1974 dropped, it is difficult to use 1975, the year after the liquidity crisis forced business to cut employment by 2.4 million people between September 1974 and April 1975.

The aggregate-production-function approach runs into some of the same problems since labor is still the principal factor of production. But it is possible to fit equations that treat 1974 as just another year with an error, and that identify a trend in total-factor productivity that is reasonably constant. To the extent that there is any doubt about it, the factorproductivity trend gives some statistical hints of a small slowdown in the early 1970s. The Brinner formulation assumes the factor productivity trend to be constant. If that trend were assumed to have slowed down by 0.1 or 0.2 percent (or more), which some equation forms and intervals yield, the projected growth of potential would be even lower than the estimates of 3.4 percent that he advances.

The concept of potential GNP is the purest Keynesian macroeconomics that can still be found. Originally, potential GNP was seen as the gauge for identifying the gap of underutilized resources, and was principally the baseline for calculating the "inflationary gap" advanced by Keynes in How to Pay for the War and still shown in basic textbooks as a method of inflation analysis. For that purpose, potential GNP must nowadays be considered thoroughly inadequate because it has nothing to say about the cost side or the dynamics of inflation. Even as a measure of demand, it focuses solely on the aggregate unemployment rate, completely leaving aside the more pressing problems of capacity bottlenecks, resource shortages, or even skill shortages within the labor market. To argue for any particular economic policy because there is a full-employment gap, as indicated by potential GNP, nowadays really is an error. To assess the inflation implications of any particular policy, one must use far more sophisticated techniques-in my view, a complete, detailed model in which the gap is just another variable.

While too crude a measure for inflation analysis, potential GNP remains an essential ingredient in the most precise method for projecting aggregate unemployment. It remains as true today as it was a decade ago 
that Okun's law is the best predictor of aggregate unemployment, and that aggregate unemployment is the dominant explanatory variable for most sectoral unemployment rates. Thus potential GNP, along with lots of other information, is needed to formulate macro policies designed to reach specific unemployment goals.

Further, the growth of potential GNP is a determinant of the overall scale of the economy. In long-term analysis of such demands as those for housing or automobiles, the aggregate growth of real purchasing power, along with demographic and other variables, determines the long-term trend values. Depending upon income elasticities, these trend values will vary systematically with the trend of potential GNP.

For these reasons, a careful formulation of potential GNP remains of importance even after the numerous limitations of this still very aggregative concept are recognized. It is my belief that we will obtain better economic performance if we resolve our doubts about potential GNP on the side of caution.

Peter K. Clark: There are some similarities and many differences between Perry's methodology for obtaining an estimate of potential GNP and the technique used in obtaining the revised series on potential GNP published in the 1977 Economic Report of the President. The most striking similarity is the estimate of 4.9 percent as the overall unemployment rate in 1976 equivalent to 4.0 percent in 1955 . This similarity is less surprising when one realizes that neither Perry's technique nor the technique implicit in the council estimate uses a structural model of unemployment; instead, both estimates are an empirical description of the rising proportion of young persons in the labor force, and rising unemployment rates for these young people relative to the unemployment rate for adults.

One of the differences in Perry's results is the strong cyclical sensitivity he finds in the labor force. For example, in 1976, Perry estimates, if the unemployment rate had been 2.8 points lower, the labor force would have been 2.8 million larger. In general, if employment increases by ten persons, between four and five additional workers enter the labor force. The reason for this large increase is the strong cyclical dependence of labor force participation rates for adult women (aged 25-64). The council's revised estimates of potential GNP assume an increase in the labor force of about 0.4 percent for every percent decrease in the unemployment rate. That implies an increase of only 1.1 million in the labor force for a drop of 2.8 points in the unemployment rate. 
Other differences between Perry's methodology and the council's include the latter's use of quarterly data, which should be more accurate in capturing the effects of cyclical variability than Perry's annual data, and its use of the capital stock and total-factor productivity rather than labor productivity. Instead of belaboring these differences, however, it may be more instructive to look at some alternative methodologies that were used neither by Perry nor by the council for a resolution of the conflict between the two potential GNP series.

As a rough check on the level of potential GNP in 1976, one may calculate the percentage change in real GNP $(Q)$ associated with a given percentage-point change in the unemployment rate by estimating an equation of the form

where

$$
u_{t}-u_{t-1}=a+b\left(\frac{\Delta Q}{Q}\right)_{t}+\epsilon_{t}
$$

$u=$ the overall unemployment rate in percent

$\Delta Q / Q=$ percent change in gross national product in 1972 dollars.

This is, of course, the first of the three equations used by Okun in his original estimate of potential GNP. Using annual data for 1953-76, the following regression results were obtained:

$$
\begin{gathered}
\Delta u_{t}=\underset{(0.18)}{1.45}-0.40(0.04) \\
\left(\frac{\Delta Q}{Q}\right)_{t} . \\
\bar{R}^{2}=0.78 ; \quad \text { Durbin-Watson }=2.37 .
\end{gathered}
$$

The figures in parentheses are standard errors. This equation says that a 1 percent increase in real GNP reduces unemployment 0.4 percentage point below what it would have been otherwise. The constant term 1.45 is an estimate of how much the unemployment rate will rise during a year in which no real growth occurs. The implied "Okun's law" multiplier is 2.5 , much less than the 3.1 reported by Perry. Regressions excluding the years 1974-76 produce Okun's law multipliers that are even smaller.

If a lagged value of percentage change in real GNP is entered in the equation in order to obtain a "longer-run" reaction of unemployment to output, the results are a lower multiplier:

$$
\begin{gathered}
\Delta u_{t}=1.73-\underset{(0.04)}{0.40}\left(\frac{\Delta Q}{Q}\right)_{t}-\underset{(0.04)}{-0.08}\left(\frac{\Delta Q}{Q}\right)_{t-1} \\
\bar{R}^{2}=0.80 ; \quad \text { Durbin-Watson }=2.40 ; \quad \text { annual data, 1953-1976. }
\end{gathered}
$$

The implied Okun's law multiplier is 2.1 . 
The same equation using quarterly data provides a similar picture:

$$
\Delta u_{t}=\underset{(0.04)}{0.38-0.02)}\left(\frac{\Delta Q}{Q}\right)_{t}-\underset{(0.02)}{0.18}\left(\frac{\Delta Q}{Q}\right)_{t-1} .
$$

$\bar{R}^{2}=0.77 ; \quad$ Durbin-Watson $=1.89 ; \quad \hat{\rho}=0.23 ;$ quarterly data, 1953:2-1976:4.

$$
\begin{aligned}
\Delta u_{t}=\underset{(0.04)}{0.0 .025}-\underset{(0.02)}{0.25}\left(\frac{\Delta Q}{Q}\right)_{t}-\underset{(0.01)}{0.10}\left(\frac{\Delta Q}{Q}\right)_{t-1}-\underset{(0.01)}{0.08}\left(\frac{\Delta Q}{Q}\right)_{t-2} \\
\quad-\underset{(0.005)}{0.05}\left(\frac{\Delta Q}{Q}\right)_{t-3}-0.03\left(\frac{0.003)}{Q}\right)_{t-4} .
\end{aligned}
$$

$\bar{R}^{2}=0.75 ; \quad$ Durbin-Watson $=1.89 ; \quad \hat{\rho}=0.27 ;$ quarterly data, 1953:2-1976:4.

The last four regression coefficients are constrained to lie on a straight line. The implied Okun's law multipliers are 2.4 and 2.0, respectively. Of course, a considerably higher multiplier could have been obtained by using quarterly data and no lagged values for output changes, but this procedure has serious specification bias due to the lagged response of labor input to output.

From these regressions, which are not influenced by a prior estimate of potential GNP, I conclude that a decrease of one percentage point in the unemployment rate would increase real GNP 2.0 to 2.5 percent. Applied to an "unemployment gap" of 2.8 percentage points in 1976, this multiplier yields a potential GNP of $\$ 1,335$ billion to $\$ 1,353$ billion (1972 prices), somewhat less than the council estimate of $\$ 1,364$ billion and much less than the lower of the two Perry estimates of $\$ 1,379$ billion. If the Okun's law multiplier is 2.5 or less, how did Perry get 3.1 ? The answer is clear: Perry's estimate of the reaction of unemployment to output is biased downward by his high estimate of potential output. The equation in Perry's table 13 is:

$$
u-\bar{u}=a_{1}\left(\frac{\bar{Q}-Q}{Q}\right)+a_{2} D 74 .
$$

The higher the level of potential $(\bar{Q})$, the lower the regression coefficient $a_{1}$, and the higher $1 / a_{1}$, the Okun's law multiplier. Although estimation of the multiplier using this form of Okun's law usually results in a slightly larger number, the increase is not large enough to change the 2.5 result when lagged values of output are included in the equation.

Aside from the rough Okun's law estimates of 1976 potential $(\$ 1,335-$ $\$ 1,353$ billion in 1972 prices) just discussed, there is other evidence that the level of productivity may have shifted downward in 1974 . The follow- 
ing equation estimates the trend and cycle in private nonfarm productivity from 1953 to 1976:

$$
\begin{aligned}
& L P=-0.55-0.0146 U R M A+0.0080 U R M A(-1)+0.00684 T I M E \\
& \begin{array}{llll}
(0.01) & (0.002) & (0.002) & (0.0002)
\end{array}
\end{aligned}
$$

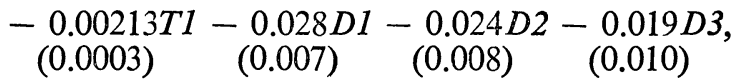

$\bar{R}^{2}=0.998 ; \quad$ Durbin-Watson $=1.53 ; \hat{\rho}=0.59 ; \quad$ quarterly data, 1953:2 to $1976: 4$. where

$$
\begin{aligned}
L P= & \text { logarithmic index of labor productivity in the private nonfarm } \\
& \text { sector, all persons } \\
U R M A= & \text { unemployment rate of men } 25-54, \text { adjusted for the sampling } \\
& \text { change in } 1967 \\
T I M E= & \text { time trend, } 1,2,3,4, \ldots \\
T 1= & 0 \text { through } 1966: 4, \text { then } 1,2,3,4 \ldots \\
D 1= & 1974 \text { dummy, equals } 1.0 \text { in } 1974, \text { zero otherwise } \\
D 2= & 1975 \text { dummy } \\
D 3= & 1976 \text { dummy. }
\end{aligned}
$$

The magnitude of the $D 2$ and $D 3$ coefficients supports the possibility that a 2 percent drop in the level of productivity has been maintained through 1976. Alternative estimates using capital inputs and total factor productivity strengthen this conclusion, since capital utilization has rebounded faster in 1975 and 1976 than has labor utilization. Although an extraordinary cyclical fall in productivity in 1974 is easy to understand, the persistence of this gap throughout the recovery years of 1975 and 1976 casts considerable doubt on the hypothesis that the post-1973 productivity shortfall is only temporary.

These two empirical checks tend to confirm the council's revised estimate for potential GNP for 1976 and to reject the figure proposed by Perry. As for the future, since both Perry's projections and ones based on the council's revised figures are trend extrapolations, neither provides a very reliable base for a forecast. However, the bad productivity performance since 1966 and the steep productivity decline in 1973-74 caution one about future productivity gains. The council's current (unofficial) projection of output at 4.8 percent unemployment in 1981 of $\$ 1,623$ billion (1972 prices), which assumes that the post-1973 productivity shortfall will be eliminated, represents a modestly optimistic view of growth in the next five years. 
George L. Perry: I disagree fundamentally with Wachter on the role of wage variables as opposed to unemployment in the estimation of the behavior of participation rates. One can think of unemployment equations as reduced forms of relations that include the real wage that matters to workers: cyclically, this relevant real wage changes with explicit wage differences like those discussed by Okun and Vroman in connection with cyclical upgrading, and with indirect differences that show up in convenience and other nonwage aspects of the job. None of this gets measured by available wage series, but it is related to unemployment. I also disagree basically with Wachter's preference for inflation variables in place of trends. I can imagine room for both and I used both. The trend variable was used to capture something quite different from inflation, a complex sociological phenomenon that economists ought to take as given and not pretend to explain in terms of a few simple macroeconomic variables. The women's movement is not simply a response to unanticipated inflation.

Nor do I believe models that assert that the participation induced by low unemployment is temporary. The biggest cyclical response is found for teenagers. Are they just reallocating toward the present their lifetime quota of work, planning to reduce it correspondingly at some later date? This view is not persuasive for any labor force group. Indeed, quite the opposite seems to be the case. Work is habit forming and being drawn into the work force in the present apparently raises the probability of being in it in the future. Thus I see no reason not to treat estimated participation effects as permanent and as a component of potential output measures.

\section{General Discussion}

Some participants discussed the possible inflationary consequences of operating at the unemployment rate underlying Perry's potential output. Robert J. Gordon reasoned that the 1955 benchmark period was one of accelerating inflation; and he noted that for more recent years, both he and Michael Wachter had obtained higher estimates of the unemployment rate associated with nonaccelerating inflation. Charles Holt questioned the use of a constant weighted unemployment rate as a standard for defining potential output. He considered both the choice of efficiency units 
as a weighting measure for different groups of unemployed and the use of 3.32 percent as a reference level for weighted unemployment as quite arbitrary. He felt that, ideally, an explicit theory of wage and price dynamics should be incorporated in deriving the weights appropriate to each group; and this theory, in turn, would provide a measure of the noninflationary unemployment level to link with the potential-output analysis.

Lawrence Klein felt that the omission of an explicit treatment of energy and resource limitations cast doubt upon the estimates of the long-run trend. Simulations with large-scale macroeconomic and inputoutput models indicate that high prices for oil and other raw materials and high energy requirements lead to large trade deficits and high inflation rates along GNP paths comparable to Perry's potential. Although cyclical recovery might allow temporary growth at rates greater than potential, the long-run path would have to be adjusted downward unless specific policies were adopted to remove bottlenecks. Franco Modigliani disagreed that trade deficits would be a hindrance in attaining potential. Either the OPEC countries would buy goods from the United States with the money they earned from oil or they would sell us the oil on credit.

Modigliani criticized Otto Eckstein's argument that the productivity trend must have declined because of a lower rate of capital formation as simply a blank assertion. Not only was the relation between capital and labor productivity uncertain, but the future growth of capital was not yet known. Robert Hall conjectured that capital might not be closely related to movements in labor productivity, supporting Perry's decision not to incorporate capital as an explicit determinant of potential output. Production-function estimates always make use of additional evidence on capital income, and although it is common practice to attribute all profits to physical capital, intangible capital might actually be a substantial part of the story. However, Eckstein cautioned that a bias understating the importance of capital stemmed from considering all technological progress as disembodied. 